\title{
Matthias Johann Eisen mõistatuste kogumise organiseerija ja publitseerijana aastatel 1869-1890
}

Rein Saukas

Eesti mõistatuste publitseerimisel on kindlasti kõige tähelepanuväärsem koht rahvaluulekogumise suurmehel Matthias Johann Eisenil (1857-1934). Enne akadeemilist kaheköitelist väljaannet Eesti mõistatused (2001-2002) ilmunud üheteistkümnest iseseisvast mõistatusteraamatust ${ }^{1}$ viie koostamise au kuulub just temale. M. J. Eiseni mõistatusteraamatutest esimene, Eesti rahva mõistatused oli omal ajal mitmele vajakajäämisele vaatamata üks sisukamaid rahvaluuleväljaandeid üldse, mis andis eesti mõistatuste repertuaarist üsna ammendava läbilõike.

Raamatu koostamiseks korraldas M. J. Eisen omalaadse kogumisaktsiooni, mille käiku ei ole folkloristid seni väärilise põhjalikkusega käsitlenud. Lähiminevikust võib nimetada siiski kaht artiklit: Erna Normanni ülevaade "M. J. Eiseni mõistatuste ja vanasõnade trükiväljaanded" ilmus Kirjandusmuuseumi aastaraamatu Paar sammukest... II köites 1961. aastal, Ülo Tedre artikkel "M. J. Eiseni tee folkloristikasse (I). "Esivanemate varandusest" "Eesti rahva mõistatusteni"” Keele ja Kirjanduse 1994. aasta 6. numbris.

E. Normann on enamikul lehekülgedest iseloomustanud hoopis vanasõnaväljaandeid - oli ju tema tollane uurimisteema samuti vanasõnad. M. J. Eiseni esimest mõistatusteraamatut käsitledes on ta väga lühidalt tutvustanud ka selle aluseks olnud materjali kogumist, hilisemate puhul on piirdutud pelgalt väljaannete endi nimetamisega. Ülo Tedre keskendub oma kaheosalises kirjutises Matthias Johann Eiseni kujunemisele folkloristiks, mõistatuste 1890. aasta väljaande materjali kogumislugu käsitleb ta küll põhjalikumalt kui E. Normann, kuid siiski kõiki allikaid kasutamata.

Mõlema oluliseks allikmaterjaliks on M. J. Eiseni kirjad Kaarle Krohnile, Ü. Tedrel ka M. J. Eiseni ajalehtedes avaldatud üleskutsed ja aruanded. Hoopis kõrvale on jäänud kaastööliste kogutud aines koos nii mõnigi kord sisukate kaaskirjadega. See peaks olema põhjenduseks veel kord tagasi pöörduda selle üsna kauge pe-

http://haldjas.folklore.eeltagused/nr21/eisen.pdf 


\section{Rein Saukas}

rioodi juurde eesti rahvaluule kogumise ajaloos. Põhikäsitlusele on lisatud ülevaade M. J. Eiseni kokkupuudetest mõistatustega kuni aastani 1887.

\section{Matthias Johann Eiseni Mõistatusse ramat 1869. aastast}

Esimesed Matthias Johann Eiseni säilinud rahvaluulekirjapanekud on mõistatused - väike kaheksaleheline pliiatsiga joonitud vihik formaadis 10,7x16,9 cm tiitliga Mõistatusse ramat. Sel 1 1se $^{\text {Detsem- }}$ ber. Vigalast, Läänemaalt. Kirjotanud M. Eisen. 1869 (SKS, Eisen 121-136). Tiitli tekst, v.a kohaandmed, on 12-aastase kirjapanija kalligraafilises lapsekäekirjas. Tiitellehele ja mujalegi on löödud praegusajaks tuhmunud ja loetamatu tempel, tagakaanele tindiga joonistatud potis kasvav hõre põõsas.

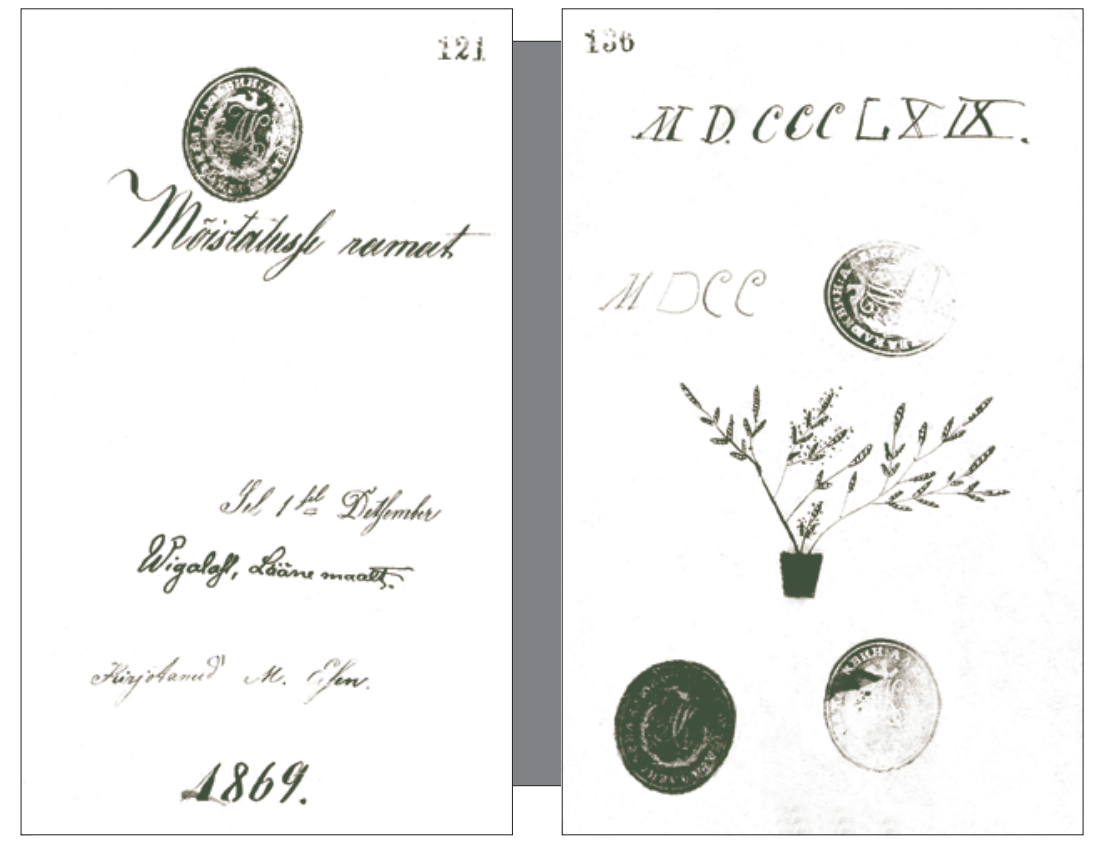

Foto 1. 12-aastase Oese koolipoisi M. Eiseni 1869. aasta mõistatuste vihiku tiitel-ja tagaleht (SKS, Eisen 121, 136). 
Kust M. J. Eisenil tuli mõte mõistatusi kirja panema hakata, ei ole teada. Hiljem, 1890. aastal mõistatuste väljaande eessõnas ei ole koostaja osanud selle kogu kohta midagi olulisemat öelda, kui et:

Käesolevat mõistatuste korjandust alustasin ju jõulukuus 1869, mil kakssada mõistatust üles kirjutasin, millele aegamööda veel teisi juurde lisasin (Eisen 1889 [1890]: 10).

Vanas eas kirja pandud autobiograafias on ta veelgi napisõnalisem ja eksitavam:

Saanud üheteistaastaseks, hakkasin juba laste jutustatud muinasjutte üles kirjutama. Kahjuks pole need kirjapanekud säilinud. Ometi on aastast 1869 alles minu esimene, 150 [siin eksib autor mõistatuste arvus - R. S.] mõistatust sisaldav korjandus (Eisen 1921: 195).

Veel neli aastat hiljem kirjeldab ta oma lapsepõlve- ja kooliaegset rahvaluulehuvi tärkamist järgmiselt:

Ennemuistseid jutte harrastasin kangesti, aga ime küll, neid ei katsunud ma ometi kirja panna. Selle asemel hakkasin kaheteistkümne aasta vanuselt rahva mõistatusi üles kirjutama. Neid panin koolilaste suust 150 tükki kirja. See oli eesti esimese laulupidu ajal. Kas ärkamisaegsed ajalehtede kirjutused selles suhtes minusse mõju avaldasid, ei mäleta ma enam. Igatahes on see mõistatuste kogu mu esimene omapärane töö (Eisen 1925: 345).

Vihikuke on omamoodi sümboolne. Vormistuse seisukohalt võiks seda pidada isegi esimeseks (olgugi et käsikirjaliseks) M. J. Eiseni enam kui 250 raamatust koosnevas rivis (Päss 1938a: 191-199). Tiitellehe kujundus annab aimu kõrgelennulisest ettevõtmisest. (Nimetagem, et üheksa aastat hiljem trükki jõudnud eesti esimene mõistatuste väljaanne kandis sama pealkirja kui noore M. J. Eiseni käsikiri.)

Vihikukesse on M. J. Eisen kirjutanud 200 mõistatust. Paarkümmend aastat hiljem, tõenäoliselt 1888. aastal, on selle omanik vabaks jäänud lehtedele lisanud veel 45 mõistatust. Lapse korjanduse seitse esimest punkti on kirjanduslikud tähemängud ja O. W. Masingust lähtuvad tekstid (Marahwa Näddala-Leht 1821-1822); nr 97-99, 101-110, 112 on kirjutatud J. V. Jannseni teosest Kues Sannumetoja... (1857). Ülejäänud jagunevad laias laastus kaheks: valdavalt 


\section{Rein Saukas}

traditsioonis olevad mõistatused (mõni siiski veidi erandlik redaktsioon) ja ilmselt kirjapanija looming. Viimase näidetena võib tuua:

EM 473: Kahe kaevo peal kasvavad kadakapõesad? Silmad; EM 833: Kuuetahaline, kaheksakandiline, üheksaotseline? [Lahendus puudub]; EM 1096: Mees lääb metsa, nopib kiva tee äärest põue? Kukk; EM 1280: Must mees, roheline kuub selgas? Maa; EM 1620: Pikka säärde, laia lemme, kivide kiri, vagude vari, ise kui haavikoemand? Läätsed; EM 1644: Pisike unnike, senna sisse situtakse, rikas listib leiba? Linnupuu; EM 1679: Pool leiva aida taga? Kuu; EM 2377: Valge sadul, mustad kirbud sees? Raamat; EM 2423: Vanamees istub nurkas, süle vett täis? Kaljaastja; EM 2685: Üks kõrend, linaluid kangeste täis? Hambad; EM 2690: Üks maailm, kaks päikest? Silmad.

Nendele tekstidele ei ole arhiivis toeks hilisemaid kirjapanekuid. M. J. Eiseni lapseeas üles kirjutatud mõistatuste autentsuskvaliteet on ta hilisemate kirjapanekutega võrreldes suhteliselt kõrge. Nii on samasse vihikusse 1888. aastal kirjutatud 45 mõistatusest 22 omaloomingulised. Vihikuke on tähtis sellegi poolest, et suur osa J. M. Eiseni enda kirja pandud mõistatustest asuvadki Mõistatusse ramatus - Anne Hussari, Arvo Krikmanni, Rein Saukase ja Piret Voolaiu koostatud Eesti mõistatuste (EM) andmebaasis on registreeritud 467 M. J. Eiseni enda ehtsat üleskirjutust, nendest 170 on 1869. aasta kirjapanekud.

Mõistatusse ramat pani aluse M. J. Eiseni hilisemale kiindumusele mõistatustesse, olles samal ajal meie rahvaluulearhiivis varaseim nii arvukalt mõistatusi sisaldav käsikiri.

Taas pöördub M. J. Eisen mõistatuste juurde seitse aastat hiljem, nüüd juba hoopis teistsuguses keskkonnas ja hoopis iselaadsel moel.

\section{Mõistatused Nalja Sõbras (1876) ja kalendrites kuni aastani 1887}

1875. aasta algul asus M. J. Eisen õppima Pärnu 6-klassilises gümnaasiumis. Noormees elas ja oli kostil Ülejõe kooliõpetaja Jaan Otstaveli (1843-1889) juures, kelle õhutusel ta hakkas luuletama, 


\section{Rein Saukas}

tõlkima, jutte kirjutama. Teda tabas tõeline kirjanduslik palang ja raamatute väljaandmise soov, mis jäi M. J. Eisenit saatma elu lõpuni. 1875. aastal valmis tal kaheksa käsikirja, 1877. aastal aga juba 31 (Eisen 1925: 349).

Väljaantava temaatika osutab noormehe üllatavale mitmekesisusele - siin leidub luulet, proosat, näidendeid, tõlkeid, ajaloolisi ja päevakajalisi teoseid (sealhulgas mitu brošüüri Vene-Türgi sõja kohta) jm. Üsna algusest hakkab M. J. Eiseni raamatutesse sugenema ka mõistatuste äärealadele kuuluvat ainestikku. Esimeseks võib pidada trükkal Schnackenburgi kirjastamisel avaldatud 74-leheküljelist raamatukest Nalja Sõber. Noore rahvale armsaks ajaviiteks (Tartu 1876), kus kuue M. J. Eiseni omaloomingulise(?) jutu järel on II osas "Mõistatuste" jaotuses toodud 13 tähemängu ja 10 keerdküsimust pealkirjaga "Lühikesed küsimised". Tähemängud on lahendustega piip, asi ja isa, uus ja suu, vesi, taevas, silmamuna, unenägu, tulevik, vihm, kotkas, laud ja haud, tuulelaev, loos ja sool.

Eesti tähemängude arhiivitausta põhjal võib väita, et siingi on tegemist M. J. Eiseni omaloominguga, mida hiljem uuesti publitseeritud ei ole. Ainult piibu-tähemäng Loe mind eest ehk takka, / Ikka seisan vakka / Sinu raske piina käes / Mis sa teed mul väetil väes... on trükitud täies mahus veel 1879. aasta Isamaa Kalendris ja tõenäoliselt sealt esimese nelja rea ulatuses rahvasuhugi jõudnud, mida tõendavad kolm kirjapanekut aastaist 1893 ja 1946. Võib oletada, et tähemängude luuletamisel oli M. J. Eisenile eeskujuks Fr. R. Kreutzwaldi toodang. Tema enda meenutustest loeme:

Luuletamise puhul otsisin enesele eeskujusid kirjandusest, nimelt vormilises suhtes. Eeskuju andsid mulle Kreutzwald, Koidula, Reinvald (Eisen 1925: 349).

"Lühikeste küsimiste" tekstid on keerdküsimuste kartoteegi järgi otsustades vastavais tüüpides kõige varasemad, sageli on tüübist hilisemaid trükivariante, nt kalendrites. Mõnel juhul taanduvad kõik arhiiviüleskirjutused trükistele. Ainult Missuguseid püksa ei ómble ükski rätsep? Argpüksa on autentsete üleskirjutustega esindatud.

Et keerdküsimuste autentsuskontroll on veel tegemata, ei saa ka kindlalt väita, et tegemist on M. J. Eiseni loominguga, kuigi selline mulje jääb. 


\section{Rein Saukas}

Peale juttude ja keerdküsimuste sisaldab väike kogumik veel kunsttükkide (põlev lumi, hüppav õun) kirjeldusi ja kentsakaid rehkendusi, s.o jutukujulisi arvutusülesandeid.

1878. aastast asub M. J. Eisen innukalt tegutsema kalendrite toimetajana: Pärnu Eesti-rahva Kalender (1879), Isamaa Kalender (1879-1887), Kodumaa Kalender (1881-1883), Kasuline Talurahva Kalender (1884-1887). Kalendrilisad on mahukad, sisaldades luuletusi, nootidega laule, originaalseid jutukesi ja tõlkeid, populaarteaduslikke kirjutisi jm. Suur osa sellest materjalist pärineb M. J. Eiseni enda sulest, autorkonna hulgas on esindatud tema ülikoolikaaslased-teoloogiaüliõpilased (aastatel 1879-1885) Jaan Bergmann, Friedrich Wilhelm Ederberg, Villem Reiman, aga ka Georg Eduard Luiga jt.

Peaaegu kõikide kalendrilisade kohustuslik osa on mõistatuste rubriik tähemängude, keerdküsimuste, mitmesuguste nuputamisülesannete ja üksikute pärismõistatustega. Vähestel kordadel on teksti juurde lisatud autor (tähemängud Fr. R. Kreutzwaldilt, A. Reinvaldilt, F. W. Ederbergilt), enamikul juhtudel on see jäänud nimetamata, mis lubab oletada, et anonüümsete tekstide loojaks on olnud kalendrilisa toimetaja M. J. Eisen ise. ${ }^{2}$ Sellele küsimusele saab vastuse anda seni veel kirjutamata uurimus mõistatuste perifeeriažanridest 19. sajandi eestikeelses kirjasõnas ja rahvaluulekogudes.

1887. aastaks on Eisen oma mõistatustehuvis läbinud kaks põhimõtteliselt erinevat perioodi - rahvaehtsa repertuaariga tutvumine Oese koolitoas koos selle jäädvustamisega käsikirjas ning enda ja sõprade-tuttavate loomingu avaldamine trükisõnas alates 1876. aastast.

\section{Matthias Johann Eisen ja mõistatuste kogumine aastatel 1887-1888}

\section{Veidi taustaks}

1887. aasta oli eesti rahvaluulekogumises üsna tagasihoidlik. Jakob Hurda stipendiaadid Johannes Härms ja Mihkel Koik kogusid Kodaverest 173 laulu 165 leheküljel. Eesti Kirjameeste Seltsi laekus 13 kogujalt kokku 14 saadetist 189 leheküljel, enamik neist paari lehekülje pikkused, lisaks Villem Mägi 100-leheküljeline korjandus. 
Jakob Hurt avaldas küll ka üleskutse setu ainestiku korjamiseks (Hurt 1887), kuid see jäi peaaegu tähele panemata.

M. J. Eiseni isiklikus elus olid aastad 1887-1888 keerulised, tema biograafid on nimetanud neid rännuaastateks. Enne kui Kroonlinn ta püsivaks ameti- ja elukohaks sai, pidas ta 1887. aasta algusest jõuludeni pastoriametit Petroskois, 1888. aasta jaanuarist maini Moloskovitsis (Balti raudtee ääres Narva ja Gatschina vahel, nagu ta kirjas sõber Kaarle Krohnile 20. aprillist 1888 selgitab), siis kuu aega Kattilas. Teenistusajal Karjalas ja Ingerimaal tuli ette võtta pikki sõite mööda kubermange, et jumalateenistusi pidada. Kõik see oli kindlasti väsitav ja kurnav. Kui inimesel kindel kodu on ja reisisid ees ei ole, siis võib ta palju hõlpsamini kõiki ko-

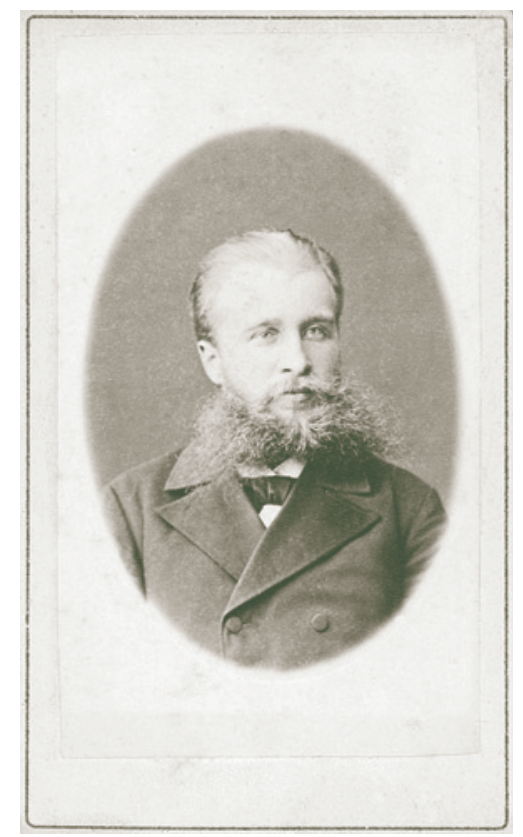

Foto 2. Matthias Johann Eisen (1857-1934). G. Jansoni foto. Peterburi 1887-1888 (EKLA, A-73: 16). husid täita, aga kui sagedaste ühest kohast teise peab liikuma, siis läheb see natuke raskeks, kirjutab M. J. Eisen 20. aprillil 1888 Moloskovitsist K. Krohnile.

Vahepeal ebaõnnestus kohasaamine kodumaal Mihkli koguduses. 1888. aasta teine pool kulus Kroonlinnas vikaarina. M. J. Eiseni introduktsioon Kroonlinna Nikolai kirikus leidis aset alles 21. veebruaril 1889. Mõni nädal hiljem, 9. märtsil laulatati ta Vuole kirikus Ella Petroniusega.

Kolmekümneaastane M. J. Eisen oli 1887. aastaks välja andnud peaaegu 50 raamatukest, millest rahvaluulet sisaldasid siiski vaid Esivanemate varandus (1882) ja Endise põlve pärandus (1883b). Ilmselt Eesti Kirjameeste Seltsi eeskujul oli ta õhutanud haritlasi rahvaluulet kirja panema - esimene üleskutse "Soov ja palve" ilmus ajalehes Eesti Postimees 1883. aastal ja kutsus kohalikke jutte üles kirjutama (Eisen 1883a). Niisiis jõudis M. J. Eisen uuesti mõistatuste juurde oma rännuaastatel. 
Rein Saukas

\section{Kogumistöö esimene etapp: üleskutsed, esimesed saadetised}

Esimesed teated M. J. Eiseni soovist ise mõistatusi välja andma hakata pärinevad kirjavahetusest Kaarle Krohniga. 1887. aasta 1. septembri kirjast loeme: Edespidi on mul nõu vanu Eesti mõistatusi välja andma hakata. Seks korjan ma aga veel materjali. Juba neli päeva hiljem, 5. septembril 1887 ilmus Postimehes M. J. Eiseni üleskutse mõistatuste kogumiseks (Eisen 1887a) ja järgneva kuu jooksul veel neljas ajalehes (Virulases 7. septembril (Eisen 1887b), Meelejahutajas 8. septembril (Eisen 1887c), Olevikus 21. septembril (Eisen 1887d) ja natuke erinevas sõnastuses ka 3. oktoobri Sakalas (Eisen 1887e)).

Lühike, ilma pealkirjata tekst oli ajalehtedes tavaliselt paigutatud mingisse rubriiki (Seltsielu. Lõbustused. Kirjandus) ega olnud veerus kuidagimoodi esile tõstetud. M. J. Eisen kirjutab, et tänini on mitmesugust vanavara ilmunud - ennemuistseid jutte, rahvalaule, vanasõnu - , mõistatusi aga mitte, ja seda kavatsevat ta nüüd ette võtta. Ta väidab end neid juba hulk aega korjanud olevat, aga ei jaksavat kõiki ise üles kirjutada, sellepärast palun kõiki, kes Eesti mõistatusi tunnevad, vaevaks võtta mõistatusi üles kirjutada ja neid hää asja edendamiseks minu kätte saata (Eisen 1887a).

Siin autor küll liialdab, sest teadaolevalt ei ole ta koolipõlvest alates mõistatusi kogunud, ja näitab üles asjatundmatust, kui väidab, et mõistatusi eri raamatuna ilmunud ei ole (C. E. Mötleja Mõistatuste raamat. Esimene korjandus ilmus juba 1878. aastal). Sama viga kordub pea kolm kuud hiljem ilmunud üleskutses "Eesti mõistatused". Oma Eesti rahva mõistatuste eessõnas nimetab ta juba enam-vähem kõik selleks ajaks ilmunud mõistatusi sisaldanud trükiväljaanded.

Kogumisega saab Matthias Johann Eiseni arvates vanavara alal hoitud ja tubli mälestussammas püstitatud. Ta seab endale eesmärgi, mida ta pea kõigis ajalehekirjutistes järgnevate kuude jooksul ei väsi kordamast: kogutud materjal tuleb kohe trükis avaldada.

Matthias Johann Eisenil ei tulnud oma tagasihoidlikule üleskutsele vastajaid kaua oodata. Esimene saadetis mõistatusi tuli Jaan Lievoh'lt Noarootsist ja kandis kuupäeva 27. september, järgmine oli postkaart Mihkel Kiiskilt (4. oktoober), S. Kääri saadetis järgnes 14. oktoobril. Et Jaan Lievoh'13 nii nobedalt sada mõista- 
Rein Saukas

tust varuks oli, selgitab tema kaaskiri 27. septembrist 1887, kus ta teatab, et juba mitme aasta eest hakkasin mina rahva suust vanu mõistatusi üles kirjutama selle lootusega, et need kuskil trükitud saaksivad (SKS, Eisen 151). Veel kirjutab Jaan Lievoh, et ta on varem saatnud mõistatusi Ado Grenzsteinile, aga see ei ole neid veel kuskil trükis avaldanud.

Tundub, et laekunud saadetiste hulk ei vastanud M. J. Eiseni ootustele ja ta avaldas sama aasta 26. oktoobri Olevikus uue üleskutse pealkirjaga "Eesti mõistatused" (Eisen 1887f).

See üleskutse on juba pikem ja pakub huvitavaid tähelepanekuid eesti mõistatuste kohta, mida varasemad kogumisloolised allikad ei sisalda. M. J. Eisen alustab sellega, et vanu, rahva suus elavaid mõistatusi on tänini koguni vähe tähele pandud ja neid enam möödaminnes korjatud. Mõistatused ei ole tema arvates vähem tähtsad kui nt laulud, kuigi nad ei anna viimastega võrreldes niisama palju informatsiooni.

Edasi juhib Matthias Johann Eisen tähelepanu eesti mõistatuste eripäradele. Mõistatustes on vahel niisuguseid sõnu, mida
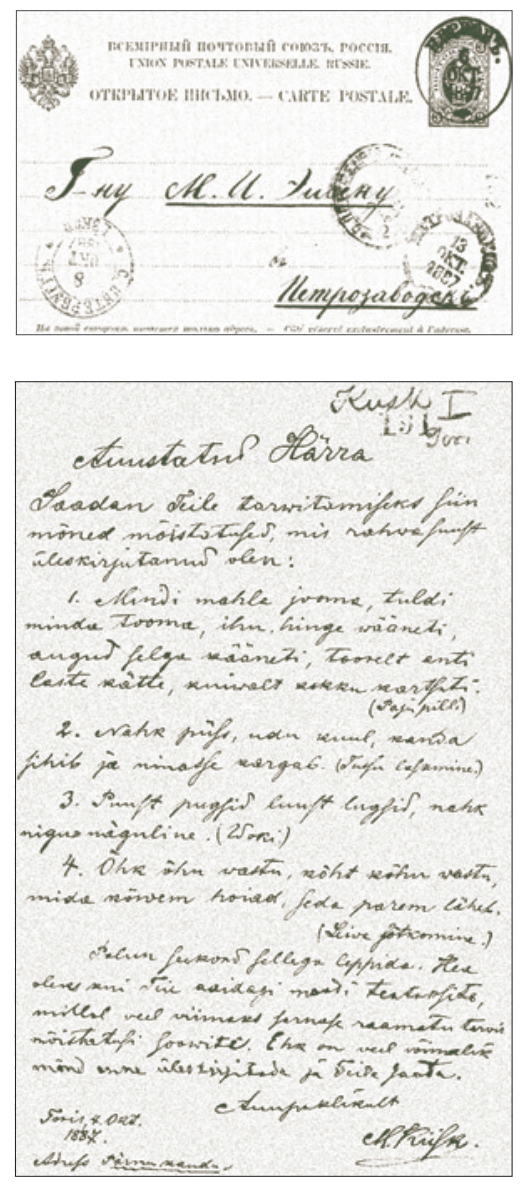

Foto 3. Tori kihelkonna põllumehe Mihkel Kiiski (1861-1939) saadetud postkaardi esikülg (ülal) ja tagakülg, millel kirjas neli mõistatust (all) 4. oktoobrist 1887 (SKS, Eisen 191-192). enam ei tunta, neid on lapsed vanematelt õppinud, nii on need suulises traditsioonis alles hoitud, ilma et neid oleks trükitud. Mõistatuste arhailine keel andvat tunnistust nende vanusest. Sellele viitavat ka sarnasus soome ja teiste hõimurahvaste mõistatustega. 


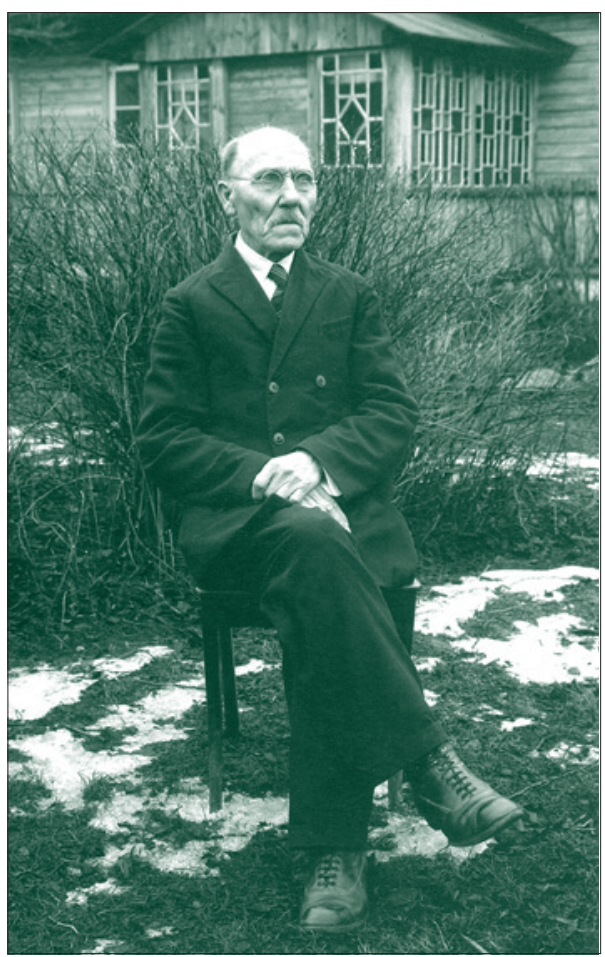

Foto 4. Kooliõpetaja ja literaat Jaan Lievoh. 1932 (EKLA, f 116, m 8: 4).
Kõik see paneb meid seda otsust tegema, et palju Eesti mõistatusi enam kui tuhande aasta vanused on, s.o nad on juba sel ajal sündinud, kui eestlased oma lähemate sugurahvastega veel ühes koos ühena rahvana elasi$v^{4}{ }^{4}$ (Eisen 1887f).

Vana aja uurijale oleks aga vajalik, et tal oleksid kõik eesti mõistatused käepärast. Edasi nimetab M. J. Eisen E. Lönnroti kahes trükis ilmunud kogumikku Suomen Kansan Arvoituksia ynnä 135 Viron Arvoituksen kanssa (Helsinki 1844) ja Suomen kansan Arvoituksia ynnä 189 Viron Arvoituksen kanssa (teine, täiendatud trükk, Helsinki 1851), mis olevat täielik soome mõistatuste kogu, kuhu on võrdluseks lisatud ka eesti

mõistatusi. Eesti mõistatusi sisaldavatest trükistest teab ta kummalisel moel lisaks nimetada vaid 425 mõistatust sisaldavat F. J. Wiedemanni teost Aus dem inneren und äusseren Leben der Ehsten (Sankt-Peterburg 1876), jättes mainimata näiteks Anton Thor Helle Kurtzgefasste Anweisung zur Ehstnischen Sprache... ja isegi C. E. Mötleja Mõistatuste raamatu.

Eesti mõistatusi üks inimene ammendavalt üles kirjutada ei jõua, sest kui ta täieliku korjanduse tahaks välja anda, peaks ta kõik Eesti kihelkonnad läbi reisima ja igal pool mõistatusi taga pärima. Et niisugusel tööl palju takistusi on, seda võib kergeste mõista. Mõistatuste kogumisega on aga kiire, sest need võivad unustusse vajuda:

Sellepärast peame töö ette võtma, niikaua kui seks veel aeg on. Me võime seda tööd aga hästi toimetada, kui iga mees 


\begin{abstract}
oma kihelkonna ehk oma pool tuttavad mõistatused üles kirjutab ja nende ridade kirjutaja kätte saadab (Eisen 1887f).
\end{abstract}

Kogumismetoodika osas on ta niisiis samadel seisukohtadel, kuhu J. Hurt oli Eesti Kirjameeste Seltsis joudnud 1876. aastal - üks inimene kogu rahvaluulet kirja panna ei suuda, seda saavad teha vaid kaastöölised, kes kohalikku ainest ja inimesi hästi tunnevad. Ka M. J. Eisen seadis J. Hurda kombel üles kogumistöö kihelkondliku printsiibi - igasse kihelkonda üks mõistatuste üleskirjutaja.

M. J. Eiseni teine üleskutse mõjus potentsiaalsetele kohalikele kaastöölistele virgutavalt: juba novembris laekus kuus saadetist (Carl Martin Redlich, Konrad Roost, Jüri Peterson, Jüri Tilk, K. Pedak, J. Paap), detsembris üks (Elisabeth Aspe) ja jaanuaris veel kaks (Hans Perkson, Toomas Tetsmann), veebruaris saatis Carl Martin Redlich veel mõistatusi.

\section{Kogumistöö teine etapp: märts - detsember 1888}

1888. aasta veebruari ja märtsi vahetusel saab täheldada olulist muutust või pööret M. J. Eiseni kogumisürituses. 1888. aasta 3. märtsi Postimehes avaldab ta kirjutise "Eesti mõistatuste asjus" (Eisen 1888a), mida saab pidada esimeseks aruandeks senisest kogumiskäigust. Esimesest üleskutsest oli siis möödunud juba viis kuud. Selles ei olnud midagi eripärast - oli ju Eesti Kirjameeste Seltski aruandeid avaldanud, seda lubas Jakob Hurtki oma 


\section{Rein Saukas}

üleskutses "Paar palvid Eesti ärksamaile poegadele ja tütardele", mis hakkas ilmuma 22. veebruaril 1888 (Hurt 1888a), ning esimest aruannet said kaastöölised lugeda juba 28. märtsil (Hurt 1888b).

M. J. Eiseni 16 kuud väldanud mõistatuste kogumise ürituse võibki tinglikult jagada kahte perioodi. Esimesed kuus kuud (september 1887 kuni märts 1888) tegutses M. J. Eisen rahvaluulekogumise organiseerimisel põhiliselt üksiküritajana, saades tagasihoidlikke tulemusi. 1888. aasta märtsist alates organiseeris ta kogumist Jakob Hurda eeskujul ning ilmselt rahvaluulekogumise üldise elavnemise taustal laekus ka rohkem mõistatusi.

Kuni aasta lõpuni jõudis M. J. Eisen erinevates ajalehtedes Olevik (6), Postimees (6), Virulane (2), Valgus (1), Sakala (1) - avaldada 16 aruannet kogumistöö käigust. Viimane aruanne ilmus 19. detsembri Olevikus. Igale ajalehele koostas M. J. Eisen eraldi teksti, sõnastuselt täiesti kattuvaid aruandeid ei ilmunud, kuigi 16 hulgast võib eristada üheksa sisuliselt erinevat aruannet. ${ }^{5}$ Aruandeid ilmus iga kuu, v.a augustis ja novembris.

Esimeses aruandes nimetab M. J. Eisen kogujad ja laekunud tekstide hulgaks enam kui 1000 mõistatust (Eisen 1888b). Aprillismais teatas M. J. Eisen kogutu arvuks 1200 (Eisen 1888f), detsembris 1770 (Eisen 1888r). Teades kogutud tekstide koguarvu, näeme, et M. J. Eisen peab arvestust mitte laekunud tekstide, vaid meie mõistes tüüpide hulga alusel. Soomlastel on enam kui 2000 vana mõistatust ja ma usun kindlaste, et Eesti mõistatuste hulk niisama suur on ${ }^{6}$ (Eisen 1888f) - seega on 2000 mõistatustüüpi see piir, milleni Eisen oma kogumistööga tahab jõuda ja mille poole ta 1890. aastal uuesti alanud kogumistööga püüdleb.

Aruannetes loetleb M. J. Eisen isikuid, kes on vahepeal materjali saatnud. Märtsi aruandes on toodud ainult nimed ja kihelkonnad, edaspidi aga juba ka kirjapandud mõistatuste hulk. Kas siin saab osutada J. Hurda mõjule, kes samuti nimetas saadetud üksuste arvu? Kogumise ajal ilmunud aruannetes on M. J. Eisen registreerinud peaaegu kõik isikud, kes talle mõistatusi saatsid. Säilikus SKS, Eisen, mis koondab kogumisürituse käsikirjad, on vaid üksikud saadetised (anonüümsed, Joosep Hurt, Jaan Lambert, H. R-e, mõni Tilkade saadetis), mille fikseerimist aruannetes ei ole õnnestunud tuvastada.

Ilmuma hakanud aruanded ja ilmselt Jakob Hurda samaaegne tegevus mõjusid mõistatuste kogumisele positiivselt. Kui esimese 5-6 kuu jooksul laekus M. J. Eisenile 14 saadetist, siis alates märt- 
sist 1888 kuni aasta lõpuni juba 64. Edukamate kihelkondade ja/või maakondade nimetamine aruannetes ja muude kihelkondade inimeste innustamine ajastule omases kõrgelennulises stiilis kandis üsna ruttu vilja.

Juba esimeses aruandes mainib M. J. Eisen maakondi, kust hästi kogutud (Pärnumaa, Läänemaa, Võrumaa, Virumaa, Tartumaa) ja kust polnud veel üldse saadetud (Järvamaa, Harjumaa, Saaremaa, Viljandimaa).

Esimestes aruannetes kurdab M. J. Eisen, et Järva- ja Harjumaalt ei ole mõistatusi saadetud. Peäro August Pitka, kes hiljem Ansomardi pseudonüümi all kirjanikuna tuntuks sai, 1887. aastast aga vabatahtlikuna Soomes Haminas kroonut teenis, on 13. aprillil 1888 kirja pannud 36 mõistatust. Samast kuupäevast pärinevas kaaskirjas kirjutab ta:

$43^{\text {mas }}$ "Postimehes" s.a lugesin ma, et Teie mõistatusi korjata, mille juurde veel lisasite, et Järva ja Harju alles uinuda, sest et neist maakondadest veel ühtki mõistatust Teile saadetud pole. Viimane ütelus, iseäranis, mis Järvamaa kohta käis (ma olen järvakas), ei olnud mulle sugugi mokkamööda, nii et silmapilk võtsin kätte ja kriipseldasin paar mõistatust, mis veel lapsepõlvest meelde olivad jäenud, paberisse ülesse (SKS, Eisen 63-64).

M. J. Eiseni hurjutamine on hinge läinud ka harjumaalastele H. Tiidermannile (29. juuli 1888; SKS, Eisen 97) ja J. Pikkelile (8. mai 1888; SKS, Eisen 87), kes mõlemad asusid oma isamaalist kohust täitma ja vastavalt 34 ja 21 mõistatust M. J. Eisenile posti panid.

Mitu kogujat (M. Karotom jt) vabandavad ja kurdavad, et aega on vähe olnud, samas on nad lootnud, et keegi teine kihelkonnast töö ette võtab, aga et seda pole tehtud, on nad ise sule kätte haaranud.

Esimeses aruandes näib M. J. Eisenit eriti hämmastavat muidu ärksa Viljandimaa rahva leigus mõistatuste üleskirjutamise suhtes:

Võib-olla ometi, et uuema aja haridus Sakalast vanad Eesti rahva mõistatused nii on ära hävitanud, et neid enam rahva suust kuulda ei ole. Mõistatuste üleskirjutajate hea tahtmise puudust ei või ma kõige vähemalt Sakalamaal põhjuseks pidada [---] (Eisen 1888a).

1888. aastal saab rahvaluulekogumise temaatika ajalehtedes sageli kõneaineks. Kohalikud lehed püüdsid omalt poolt nii M. J. Eisenile 


\section{Rein Saukas}

kui ka J. Hurdale tuge pakkuda. 1888. aasta 16. aprilli Sakala õhutab maakonna rahvast M. J. Eisenile mõistatusi saatma: Igal haritud rahval on nende vanavara, nende targad sõnad ja mõistatused hoolega kirja pandud - tõtaku ka meie noor sugu selles töös töötegijaile abiks olema.

3. mai aruandes "Eesti vanade mõistatuste korjamise aruanne" loetleb M. J. Eisen juba 22 kihelkonda, kust on mõistatusi saadetud, kogumistööst on puutumata jäänud ikka veel Järva-, ${ }^{7}$ Saareja Hiiumaa (Eisen 1888h).

Eriliselt on M. J. Eisenil põhjust esile tõsta Tori kihelkonda, kust kuus kaastöölist (Mihkel Kiisk, A. Martson, Karl Kirschbaum, Jüri, Mihkel ja Tõnis Tilk) saatsid 11 korral kokku 661 mõistatust, mis on $11,7 \%$ talle laekunud tekstide koguhulgast. 17. septembri aruandes "Eesti rahvamõistatused" kirjutab M. J. Eisen tunnustavalt:

Kiituse väärt usinusega ja iseäranis rohkesti mõistatusi on Tori kihelkonnast korjatud, kus palju agaraid isamaa armastajaid $^{8}$ nähikse olevat (Eisen 1888n).

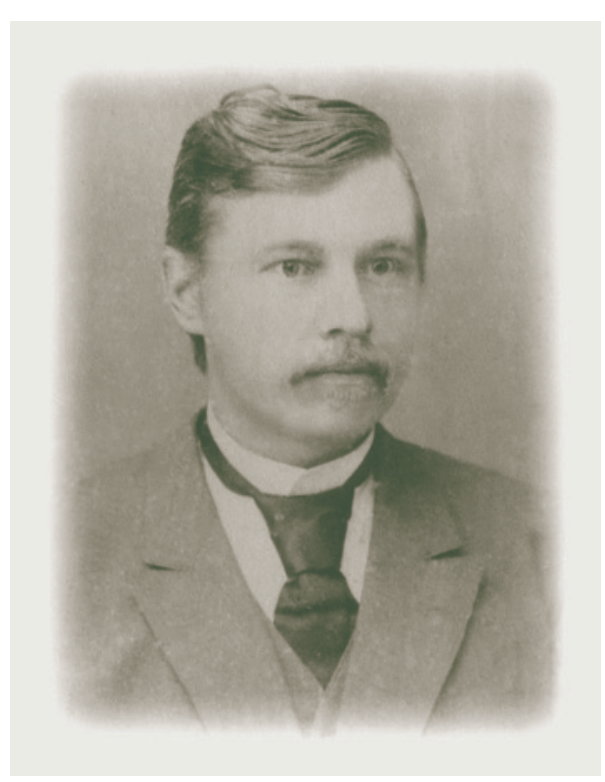

Foto 6. Üks kuuest kaastöölisest Pärnumaalt Tori kihelkonnast - kooliõpetaja Jüri Tilk (EKLA, A-95: 42).
Sügisel on kogumistöö juht sunnitud aga tõdema, et töö soiku hakkab jääma:

[---] saatmise seismajäämise pärast ei jää muud nõu üle, kui mõistatuste kogu pea trükki anda ehk küll kihelkondasid veel oige küllalt leida, kust mitte ühtki mõistatust pole tulnud (Eisen 18880).

Kui arvestada, et kevadtalvel oli oma rahvaluule kogumise töö väga jõuliselt ja edukalt käivitanud Jakob Hurt, pole põhjust imestada, et M. J. Eisen oma üritusega varju jäi. Tema ebakorrapärased aruanded, impersonaalne pöördumine 


\section{Rein Saukas}

kogujate poole ning saadetiste ja saatjate üleslugemise lünlikkus ei avaldanud mõju. Jakob Hurda kohene kiitus ja oma nime lehest lugemine oli ilmselt suuremaks innustajaks kui Matthias Johann Eiseni aruandest aruandesse korduvad lubadused raamat peagi trükki anda.

Et koguja ootas ajalehest märki oma saadetise päralejõudmise kohta, annab väga selge tunnistuse Rakvere kihelkonna Kohala põllumehe Mart Tamme juhtum. 6. augustil saatis ta kibedal töö ajal (SKS, Eisen 30) 40 mõistatust. Et M. J. Eisen saadetist 17. septembri aruandes ei nimetanud, oli koguja sunnitud sama materjali saatma juba teistkordselt, sest vistist läks seekordne kiri kaduma, sellepärast saadan veel nü̈d viimsel otsal, ehk on veel mõni siin hulgas, mis teile pole saadetud (SKS, Eisen 34).

Pärast seda, kui ka Jakob Hurt 1888. aasta veebruaris-märtsis rahvaluulet koguma hakkas, seisid mitmed M. J. Eisenile saatjad probleemi ees, kuidas nad edaspidi peaksid toimima. ${ }^{9}$ M. J. Eiseni kaastööline Jüri Tilk sõnastab 18. juunil 1888 saadetud kirjas oma kõhklused järgmiselt:

Ma ei tea aga mitte, kas neid ka temale [s.o Jakob Hurdale -R. S.] veel vaja saata on, mida Teile saatsin, või ei. Kui seda tarviliseks arvate, siis oleks hä̈̈, kui mulle seda postikaardiga teataksite. Kui vaja saata pole, siis pole ka tarvis kirjuta$d a$ (SKS, Eisen 213-214).

Helene Maasen tunnistab aga 21. septembril 1888 ausalt, et kuna M. J. Eiseni austatud ametivend J. Hurt ka igasugust vanavara korjab, saatis ta oma kogutud mõistatused ja muu rahvaluule talle, seda arvab ta teisigi kogujaid teinud olevat (SKS, Eisen 385).

Kahe rahvaluulekogumise organiseerija üheaegne teotsemine on toonud Eesti Rahvaluule Arhiivi kogudesse palju kattuvat materja-

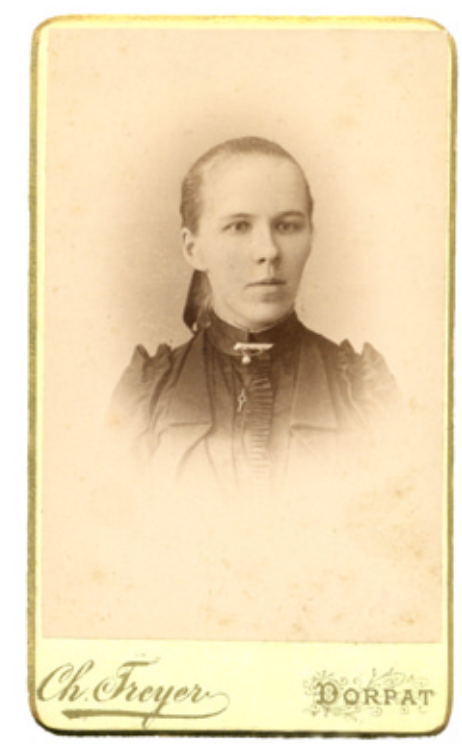

Foto 7. Uks väheseid naiskaastöölisi taluperenaine Helene Maasen (1869-1933). C. Treyeri foto. Tartu (EKLA, A-10: 19). 


\section{Rein Saukas}

li, mille väljaselgitamine on olnud lühivormide akadeemiliste väljaannete ettevalmistamisel üsna tülikas ja aeganõudev. Pakun siin lihtsalt loendi nendest M. J. Eiseni 1887.-1888. aasta korrespondentidest, kes sama mõistatusainese ka J. Hurdale on saatnud: Johannes Bracks Peterburist, Jaan Kripson Võnnust, Gustav Tenter Maarja-Magdaleenast, Helene Maasen Palamuselt, Juhan Mein Suure-Jaanist, Jaak Toss Viljandist, Johann Pastarus Helmest, Johann Mägi Tartu-Maarjast, Peeter Ruubel Hallistest (J. Hurdale läkitas ta murdekeelsed, M. J. Eisenile kirjakeelsed tekstid), Karl Kirschbaum Torist, Jüri Peterson Vändrast, Jaan Lievoh Noarootsist, Hans Perkson Mihklist, Heinrich Tiidermann Harju-Jaanist, A. Redlich Amblast, Nigolas Otto Jõhvist, H. Redlich Jõelähtmelt.

M. J. Eisen lõpetab oma kogumistöö 1888. aasta jõulude eel. Viimasest aruandest, dateeritud Kroonlinnas 9. detsembril, on lugeda:

[---] palun sõbralikka korjajaid ikka veel edasi korjata. Edaspidised saadetused võivad lisas aset leida. Ja raamatu ilmumisega võib korjandus palju elavamaks minna. Siis näeb igamees, missugused mõistatused juba üles kirjutatud ja missugused veel tarvis üles kirjutada, et ilma asjata tööd poleks tarvis teha (Eisen 1888p).

\section{Kogujad oma kogumistööst: kellelt koguti, mõistatused rahvasuus, ebatsensuursed mõistatused jne}

On üldteada tõsiasi, et varasemad mõistatuste korjandused, nagu ka vanasõnade-kõnekäändude kogud, ei sisalda täpseid andmeid informantide kohta. Tavaliselt neid pole olnudki, sest kaastöölised kirjutasid üles endale teada-tuntud mõistatusi ehk teisisõnu - olid ise nii informandid kui ka materjali kirjapanijad.

M. J. Eisen ei andnud üleskutsetes ega hilisemates aruannetes täpsemaid juhiseid ega soovitusi, kellelt ja kuidas mõistatusi üles kirjutada, ainult kogumise poole peal, 6. juuni aruandes teeb ta sellest põgusalt juttu:

Kõige parem ja hõlpsam mõistatuste korjamise viis oleks ehk järgmine: kui mitu inimest koos, siis hakatagu üksteisele mõistatusi üles andma. Mis siis ühele meelde ei tule, tuleb teisele 
meelde ja sel kombel saab palju mõistatusi. Muidu aga, kui otse mõistatusi küsima hakkad, on neid palju raskem kätte saada (Eisen 1888i).

Kogujad ise on aga lisanud oma mõistatuste kirjapanekutele ka täiendavat informatsiooni. Kõige tavalisemad lisamärkused saadetisel kõlavad, et rahvasuust ja üles kirjutatud nõnda, kuidas rahvas räägib (M. Falk, Konrad Roost, Nicolai Jegorov, M. Karotom, Mihkel Kiisk, Mihkel Tilk). Rida kogujaid pakub aga juba konkreetsemat teavet. Heinrich Tiidermann on mõistatused enamiste kõik vanainimeste suust korjanud, kes sugugi kirjandust ei loe ega mõistagi (29. juuli 1888; SKS, Eisen 87).

Mihkel Tilk Torist on jälle saanud mõistatusi ühest naabri perest, kaugemale minemast takistanud ajapuudus (10. aprill 1888; SKS, Eisen 235). Tartu ülikooli meditsiiniüliõpilane Jaan Miländer saadab üksi oma kodust, s.o Saarde kihelkonnast kuuldud mõistatusi (17. juuni 1888; SKS, Eisen 259). Johann Mägi Tartu-Maarja Kavastust kirjutab mõistatusi üles mitte kohalikelt inimestelt, vaid nendelt, kes kaheksa aasta eest Karksi vallast sinna rännanud olid ${ }^{10}$ (16. oktoober 1888; SKS, Eisen 276). Jaan Leppik Paistust tähendas üles 144 mõistatust tõenäoliselt oma teadmusest, sest kui ta neid peresi mööda oleks otsimas käinud (dateerimata; SKS, Eisen 334), kujunenuks saak suuremaks.

Seda loendit saab täiendada veelgi. Jaan Kripson Võnnust märgib üles neid, mis poisikese põlvest meelde on jäänud (7. juuli 1888; SKS, Eisen 404), Joh. Voites, samuti Võnnust, on oma isa ja ema käest korjanud, kes ligi 80 aastat vanad ja Kambja kihelkonnas SuureKambja vallas kasunuvad on (25. märts 1888; SKS, Eisen 405), Urvaste kooliõpetaja J. Paap aga koolilastelt (1887; SKS, Eisen 426), Tartu Ülikooli raamatukogu kauaaegse juhataja Friedrich Puksoo isa Jakob Puksov oma pere käest, kuid ka kartuleid korjamas käinud setudelt, viimased olevat aga kõik kirjas F. J. Wiedemanni raamatus Aus dem inneren und äusseren Leben der Ehsten (5. oktoober 1888; SKS, Eisen 437, 440).

Loetletud notiitsid on kõik tõsiselt võetavad. Kogujate autentsed kirjapanekud ei anna alust kahtlustada neid lisatud andmete võltsimises. Tõsise umbusuga tuleb aga suhtuda Carl Martin Redlichi kirja 19. veebruarist 1888, milles ta teatab M. J. Eisenile:

Ehk läheb mul ka veel korda siin nurgas mõnda tundmata mõistatust ülesse kirjutada võida, kus, nagu mulle teatatud, 


\section{Rein Saukas}

paar vanaemakest elada, kellede mälestus mõistatuste, vanasõnade, laulude poolest "väga rikas" pidada olema. Selleks pole ma ikka veel seniajani mahti saanud (SKS, Eisen 6).

Tegelikult ei ole usutav, et C. M. Redlich üldse kogumas käis - peaaegu kõik tema üles kirjutatud mõistatused tunduvad olevat omalooming.

Kaks kogujat - Jaan Lievoh ja Carl Martin Redlich - on tunnistanud oma huvi mõistatuste kogumise vastu juba enne M. J. Eiseni vastavat üleskutset. Lievoh' korjandusest oli juba eespool juttu. Carl Martin Redlich kirjutab isikliku mõistatustehuvi kogu kohta järgmist:

Ka mina korjasin neid omal ajal, umbes aasta 15 eest, ja mul oli neid siis juba kaunikene kogu koos. Väga kahju aga, et mul seda kladet enam ei ole. Ma andsin ta ühe tuttava kätte, kus ta veel praegu piab olema, kui ta kaduma pole läinud. Sellepärast olen ma aga nüid nimetatud mehele kirjutanud ja teda tagasi nõudnud (SKS, Eisen 2 ).

Mida C. M. Redlichi klade võis sisaldada, kas väljakirjutusi trükistest, omaloomingut või hoopis rahvapäraseid tekste, jääb muidugi igaveseks teadmata. Ometi annavad sääraste (eelkõige oma tarbeks) koostatud kladede olemasolust kinnitust hilisminevikus arhiivi jõudnud eksemplarid. ${ }^{11}$

Kogumistöö tõsidust iseloomustab tõik, et agaramad ja kohusetundlikumad kaastöölised tegid oma kogumistööd alustades tutvust varasemate (ka vanade ja teaduslike) mõistatusväljaannetega, et mitte saata juba trükitud mõistatusi, mille eest M. J. Eisen oli korduvalt ja tungivalt hoiatanud. Carl Martin Redlich saadab 12. novembril 1887 mõistatusi, mida ta Hupeli kogus ja mujal pole [---] mitte silmanud (SKS, Eisen 2). Kas C. M. Redlich August Wilhelm Hupeli grammatikat lugenud oli, ei oska öelda, aga kopeerimisallikana ta seda tõesti ei kasutanud.

Villem Kullerkupp on vaadanud läbi kättesaadavad mõistatusi sisaldavad trükised, tutvumata jätnud aga C. E. Mötleja Mõistatuste raamatuga (SKS, Eisen 58). M. Oidermanil on aga nimetatud väljaanne käepärast olnud, ta on selle hoolega läbi vaadanud ja saadab nüüd M. J. Eisenile ainult neid mõistatusi, mida raamatus ei leidu ja niisuguseid on kokku ainult 24. Kihelkonnakooli õpetajal S. Kääril on kasutada olnud Helsingis 1869. aastal ilmunud A. Ahlqvisti 
Suomalainen murteiskirja tahi lukemisia viron, karjalan, vatjan, vepsän ja liivin kielillä suomalaisten sanastojen kanssa ja ta ei ole oma korjandusse pannud neid mõistatusi, mis seal juba trükitud olid. M. J. Eiseni diletantliku suhtumise tõttu variantide ülestähendamisse koos tõsiasjaga, et osa kaastöölisi teda pimesi järgis, jätsid just usaldusväärsed kaastöölised kindlasti palju variante üles märkimata.

Kogujad on teinud tabavaid tähelepanekuid mõistatuste leviku kohta rahva hulgas, iseloomustades mõistatust kui juba hääbuma hakkavat liiki, mis olevat saanud laste, aga ka vanade inimeste pärusmaaks, keskealised inimesed neid enam üksteisele ei esitavat, pidades seda tühjaks asjaks, nagu märgib Juhan Aab 18. septembril 1888 (SKS, Eisen 26). Kodukanti peetakse vanavara leidumuse seisukohalt vaeseks, kõik olla meelest ära läinud, selgub Helene Maaseni kirjast 21. septembrist 1888 (SKS, Eisen 386). Üsna üksmeelselt toonitavad mitu kogujat (Peäro August Pitka, Mihkel Tilk, M. Oiderman, Jakub Reial), toetudes enda ja teistegi inimeste arvamusele, et veel mõnikümmend aastat tagasi oli mõistatamine rahva hulgas hoopis laiemalt levinud. Tori korrespondent Mihkel Tilk kirjeldab 10. aprillil 1888 olukorda üsna värvikalt:

Muidugi on need mõistatused, mis nüid veel rahva suus leida on, üks veike osa vana mõistatustest. Umbes 40-kuni 50-aastased inimesed räägivad sagedaste, et sel ajal, kui nemad lapsed olnud, palju võsavillemid olnud ja sellepärast pidanud nad 6kuni 7-aastaselt juba vanaemaga seltsis lambid hoidma minema, ja et lastel aeg igavaks ei läheks, hakanud vanaema mõistatusi mõistatama ja kõiksugu vanamoodi jutta rääkima. Nüid aga ütlevad nad kõik enamiste ära ununud olevad, sest et nad mõnel ajal ei olla enam neid kuulnud. Ka mõnigi mees ütleb: kahju, oleks sel ajal keegi üles kirjutanud, ehk jälle: kes siis seda teadis, et nüid veel niisugusid asju tahetakse - oleks seda teadnud, siis oleks võinud paremine meeles pidada! Aga mis möödas, see on möödas. Veel minu vanaisa mõistatas mulle ka ainult mõne mõistatuse, nüid aga ei kuule keegi laps enam ühtki mõistatust. Nii tahavad siis vanad mõistatused hoopis rahva suust ära kaduda (SKS, Eisen 230).

Mõistatuste tuntuse osas ei jaga kõik kogujad ülaltoodud pessimismi. Jüri Tilk Torist on veendunud, et mõistatusi on piisavalt saada, et nii kohe seda kaevust tühjaks tõsta on täitsa võimata, kuna allik nagu kuivamata näitab (8. november 1887; SKS, Eisen 206). Mõista- 


\section{Rein Saukas}

tusi loodavad juurde koguda ka Peeter Ruubel ja Johann Mägi, kes 16. oktoobril 1888 arvab, et Kavastust mõistatusi hästi saan leidma (SKS, Eisen 276), ning 236 teksti kirja pannud HansUtso, kes lubab saata veel järele, kui veel korjan (dateerimata; SKS, Eisen 304).

Siiski jäi enamikul lubajatest teine korjandus M. J. Eiseni kõnealuse kogumisaktsiooni käigus saatmata, nende nimesid kohtame aga hiljemgi nii J. Hurda kui ka M. J. Eiseni kaastööliste hulgas. Kogumistööd takistavate asjaoludena nimetatakse aja ja kogujate puudust. Rahva suus on mõistatusi veel palju olemas, aga ei ole korjajaid. Siin olen ma mõne oma pere käest üles tähendanu, ei luba ju aeg suuremaid sammusi teha! tunnistab Jakob Puksov 5. oktoobril 1888 (SKS, Eisen 440).

Mitmed kogujad on mõistatuste üleskirjutamisel tõstatanud lisaküsimusi. Kõigile vähegi eesti mõistatuste repertuaari tundvatele inimestele on teada, et seal on palju trükimusta mitte kannatavaid sõnu või sisult siivutuid tekste. Karl Kirschbaum Torist kirjutab 7. juulil 1888:

Siin nende mõistatuste seas on mõned kaunis ropud ja mis vist trükitud ei saa, aga ma kirjutasin nemad sellegipärast ülesse, teie saate ju isigi välja valitsema, mis teil tundmata ja sündsad on (SKS, Eisen 204).

Või teine Tori kihelkonna kaastööline Jüri Tilk, kes on pidanud vajalikuks M. J. Eisenile 8. novembril 1887 teatada:

[---] aga et mitmed neist siin külles natuke teisiti kõlavad, siis olen ikka kõik üles pistnud, mida ette üteldi. Siis on nende kohta veel seda ütelda, et mõnes natuke liig vähä viisakaid sõnu ette tuleb; siiski loodan ennast seega vabandada võivat, et noodavidaja selle pääle vaadata ei või, missugused kalad noota juhtuvad, vaid seda tündrisse laduja hoolde jätab (SKS, Eisen 205).

M. J. Eiseni kaastöölised toimisid siivutute mõistatustega erineval viisil. Haritud mees Jaan Jaakson kirjutas need korjanduse lõppu eri formaati paberile, pani pealkirjaks "Mõistatuste lisa" ja lisas vabanduse: Palun seda mitte pahaks panna, kui ma siia iseäralise lehe pääle mõned mõistatused ülesse märgin, mis mitte tõiste sekka ei "kõlba". Need on ju niisama kui tõisedki kallis vanavara. Lahendused nendele mõistatustele annab J. Jaakson aga võõrkeeles, nagu Ise pikk ja pera must, suure juure, jombi taga? Penis, Hoden; Suu on, silmi ei ole, nägu on, nina ei ole, habe on, hambaid ei ole? Clytoris (SKS, Eisen 325-326). 
Rein Saukas

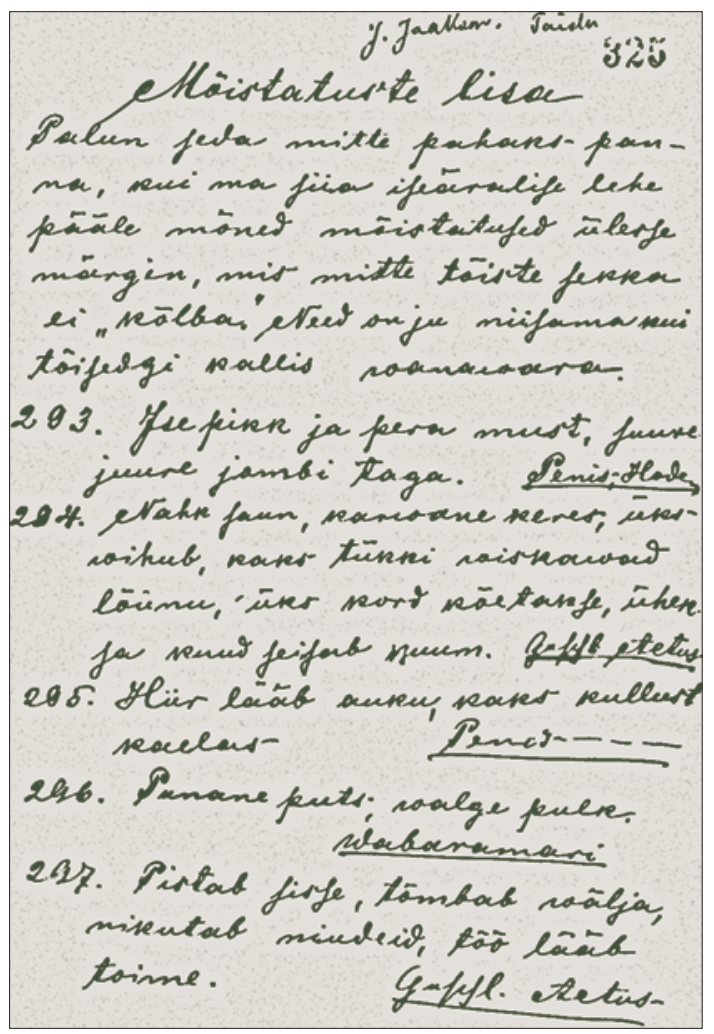

Foto 8. Lehekülg Jaan Jaaksoni saadetisest (2.-24. mai 1888-kirjutamist on alustatud lihavõttepühadel) eri formaati paberil pealkirja "Mõistatuste lisa" all on ta pannud kirja valiku roppe mõistatusi (SKS, Eisen 325).

Mõnel juhul on kogujad lisanud materjalile omapoolseid täpsustusi. Näiteks Jüri Tilk on eriliselt ära märkinud talle ja informandile arusaamatuks jäänud tekstid. 1887. aasta 23 . novembri saadetise kaaskirjast loeme: Mõnedele, mis etteütlejal enesel poo[l]segased olivad, olen küsimärgi juurde pannud; ehk saadab mõni tõine neidsamu selgemasti (SKS, Eisen 222).

Detailne mõistatuste süstematiseerimine võimaldab hinnata, kas ja kuivõrd pädevad olid Jüri Tilga omaaegsed tähelepanekud. Ta on teinud küsimärgi viie mõistatuse juurde. 


\section{Rein Saukas}

Lükka rulli, tõmba rulli, kui tõmbad, siis rulli silmad paistetanud? Veepanged (EM 2306 Eb; SKS, Eisen 218 (111)) - tüüp on valdavalt võru- ja tartumaine, antud juhul on tegemist üsna harukordse Pärnumaa lokaalredaktsiooniga: kui mujal on tavaline lahendus otspaja, pajalaud, siis siin veepanged, kaev, kui mujal lükatakse lülli, siis siin rulli.

Üks ütleb: öö pitk, teine ütleb: päev pitk, kolmas ütleb: igavene elu veel pitkem? Ase, iste, pada (EM $2738 \mathrm{~A}_{13+}$; SKS, Eisen 220 (141)) on tõesti erandlik ja arusaamatu lõpuosaga variant.

Kitu käib mööda teed, tõstab tõist, tõstab tõist, püstab kõhna? Kuhjategemine (EM 1971 Õ = 2305 W; SKS, Eisen 220 (145)) - tekst on ainulaadne kontaminatsioon heinakoorma ja hobuse rakendamise mõistatustest.

Kõrgem kui sääsk, madalam kui sääsk, rohkem auka sees kui kuninga kojal aknaid? Puuriit (EM 1635 F; SKS, Eisen $221(149))$ - jälle väga erandlik variant.

Ilves nutab, lemsi laulab, sarapuu süda sadanu, tammekand ei kõigata? Laps, lapsehoidja, ema, isa (EM 344 Ea; SKS, Eisen 221 (150)) - mõistatuse peamine levikuareaal on saared ja Viljandimaa, Pärnumaalt ainult kaks üleskirjutust.

Nagu eelnevast näha, on Jüri Tilga küsimärgid, s.t tähelepanekud, igati õigustatud, sest kolmel juhul on tegemist erandlike, kahel juhul üsna haruldaste Pärnumaa variantidega.

Mõistatusi üles kirjutades on korrespondendid sageli tunnetanud, et kirjakeele graafilistest vahenditest ei piisa kõigi murdeerisuste tähistamiseks. Jakub Reial Kolga-Jaanist on 1888. aastal omaalgatuslikult märkinud palatalisatsiooniga sõnu:

Kirjaviisis olen nõnda pü̈̈dnud kirjutada, kudas Viljandimaal Kolga-Jaani kirikuvalla rahvas räägib, kust rahva suust need mõistatused ka on saadud ('peenendaja, peenendadava tähe ees, kui kaks peenendadavad tähte kôrvu on, siis keskel) (SKS, Eisen 353).

Reiali kirjaviisi kohta esitan siin kaks näidet:

Po'ol siga, po'ol puud? Piäari (SKS, Eisen 357 (6));

Valge vaa't, punane pulk? A'ni, nokk (SKS, Eisen 357 (9)).

Palatalisatsiooni on pidanud vajalikuks märkida ka Tõnu Sander Pilistverest: 
Rein Saukas

Ani all'as, pia pall'as, nina niinega seotud? Viht (SKS, Eisen $377(11))$;

All'ärg, auk sell'as? Veski kivi (SKS, Eisen 378 (26)) jms.

Jaan Jaakson Paistust seletab murdevorme ja sõnu, mis arvab kirjakeelt või teist murret kasutavale inimesele arusaamatud olevat:

Mees alasti, hame puhus (kirjak. põues)? Küünal (SKS, Eisen 305 (7));

Kuningas istub kulla sees? Rahu (kirjak. neerud) rasva sees (SKS, Eisen 307 (30));

Mis kerkib ilma sepata (permita)? Villad (SKS, Eisen 309 (57)).

Ta lisab ka mõnel korral omapoolseid kommentaare. Meie näeme iga pääv, kuningas harva, Jumal ei iialgi? Iseenesesugust (SKS, Ei-

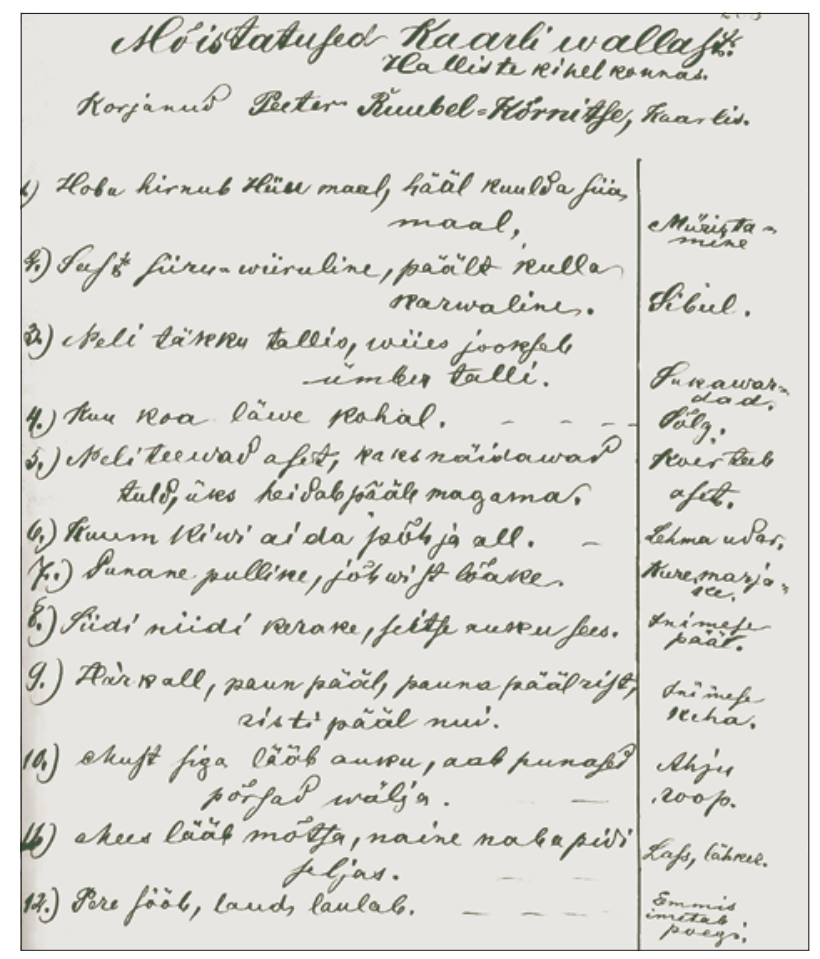

Foto 9. Halliste kihelkonna Kaarli vallakirjutaja Peeter Ruubeli (1868-1932) saadetise esimene lehekülg 13. novembrist 1888 (SKS, Eisen 263). 


\section{Rein Saukas}

sen 311 (90); EM 350, tüübis tegelikult 115 autentset varianti) kohta arvab ta, et see mõistatus ei näita rahva oma olevad ja on vist raamatutest rahva suhu saanud (SKS, Eisen 311). Mõistatusel Kui öösel voodis hingad sa, siis taga tare tantsin ma? Tuul olevat aga uue aja heli juures (SKS, Eisen 315).

Murdesõnade seletusi leidub ka Hans Utso korjanduses: Tanumi tont, usse (õue) uint? Värat - koer (SKS, Eisen 297 (158)); Säält suur sõda sõidab, kust ei mahu kassi händ (saba)? Linnupuu (SKS, Eisen 299 (190)).

Korjandused sisaldavad üllatavalt vähe mõistatuste perifeeriasse puutuvat ainest, järgnevatel aastatel nii M. J. Eisenile kui ka J. Hurdale saadetu hulgas leidub seda juba tunduvalt rohkem. Ilmselt püüti uuemana tundunud keerdküsimusi mitte üles märkida, kõneles ju M. J. Eisengi üleskutsetes eesti mõistatuste aukartust äratavast vanusest. Nii kirjutab Jakob Koit ühe tähemängu Kui eest loed, siis temata perenaine korda ei saa, kui tagant loed, siis temata rätsep korda ei saa? Tiin, niit (SKS, Eisen 43 (76)). Üksikuid keerdküsimusi ja liitsõnamänge on pannud kirja Heinrich Stein: Millal tulevad naesed tagurpidi tuast välja? Kui tuba kü̈̈rivad ((SKS, Eisen 75 (37)); Mihkel Tilk: Mitu sammu astub varblane aastas? Ei ühtegi, ta hüppab ainult ((SKS, Eisen 227 (37)) ja veel mõned.

Saadetiste vormistamisel kasutatud pealkirjad annavad aimu rahva seas käibinud terminoloogiast. Pealkirjadeks on: Mõistatused, Saarlaste mõistatused, Vanad mõistatused, Vanarahva mõistatused, Eesti vanad mõistatused, Eesti mõistatused, Eesti rahva mõistatused, Eesti rahva vanad mõistatused, Vanad rahva mõistatused, Mõistu sõnad, Mõista, mõista, mis see on!, lahenduste puhul kasutatakse termineid: Mõistatuste seletused, Mõistatuste otsused, Seletus, Vastus.

\section{Matthias Johann Eiseni kaastöölised}

Aastatel 1887-1888 oli M. J. Eisenil 67 kaastöölist. Selle arvu üle võib küll natuke vaielda. Olen arvestanud selle kogumisaktsiooni materjalide hulka kõik säilikus SKS, Eisen leiduvad korjandused, lisaks Julius Tiedemanni korjanduse, mille M. J. Eisen on paigutanud oma põhikogusse E 128-163, 166-168. J. Tiedemanni rahvaluulekirjapanekud (lisaks mõistatustele veel vanasõnu ja laule, kokku $62 \mathrm{lk}$ ) pärinevad aastast 1870, kuid jõudsid M. J. Eiseni kätte alles 1888. aasta lõpul Saraatovist, kus J. Tiedemann pastori- 
ametit pidas (Eisen 1888p). (Elmar Päss väidab, et juba üliõpilasena omandas Eisen mõne väikse rahvaluulekorjanduse, nagu Tiedemannilt ja Undritsilt (Päss 1938b: 133).)

M. J. Eiseni aruannetes ei nimetata J. Lambertit, M. Kampmanni, Sööti ja J. Hurta, pseudonüümi H. R-e all saatnud kogujat, samuti kolme täiesti anonüümseks jäänud isikut ning ühte Jüri Tilga ja ühte Tõnis Tilga saadetist, mis kõik leiduvad kogus SKS, Eisen. Üks Oleviku toimetusele 27. juulil 1887 läkitatud anonüümne saadetis (SKS, Eisen 435-436) Rõugest on seega varasem kui M. J. Eiseni esimene üleskutse mõistatuste kogumiseks, kuid ta on kasutanud seda oma väljaande koostamisel (EM $566 \mathrm{~J}_{2} \mathrm{a}, 1042 \mathrm{~A}_{3} \mathrm{~d}_{1}$ ).

Aktsioon tõi M. J. Eisenile 78 saadetist 5647 mõistatusega. Suuremad kogused mõistatusi on kirja pannud Julius Tiedemann (306), Jaan Jaakson (303), Jakob Koit (252) ja Hans Utso (236), väikseim saadetis on Söödilt (kolm mõistatust), Jaan Lambert, Mihkel Kiisk ja Mihkel Kampmann on saatnud igaüks neli mõistatust. Üks saadetis sisaldas keskmiselt 72 mõistatuse üleskirjutust.

M. J. Eiseni kaastöölised saatsid talle tavaliselt ühe korra, kordade arvu poolest ületab teisi Jüri Tilk kolme saadetisega, kaks saadetist on läkitanud Mihkel Kiisk, S. Käär, Jaan Lievoh, Carl Martin Redlich, Jakub Reial, Mart Tamm ja Mihkel Tilk. Tähelepanuväärne hulk kogujaid (22) tegid oma ainsa kogumiskatse M. J. Eisenile, ei varem ega hiljem pole nad rahvaluulet kirja pannud: Juhan Aab, M. Falk, H. R-e, Jaan Jaakson, Nicolai Jegorov, S. Käär, A. Martson, Jaan Miländer, M. Oiderman, J. Paap, K. Pedak, J. Pikkel, Jakub Reial, Aleksander Martin Saar, Heinrich Stein, Peeter Unt, Hans Utso, Joh[annes] Voites ja neli anonüümseks jäänud isikut.

Kahel M. J. Eisenile saabunud mõistatuste korjandusel puuduvad igasugused andmed (koguja, kogumiskoht ja -aeg). Mõistatuste andmebaasi toel on aga võimalik teha ka nende saadetiste geograafilise päritolu kohta üsna tõepäraseid oletusi. Juba põgusal jälgimisel saab täheldada, et 26 mõistatusest koosneva korjanduse (SKS, Eisen 449-451) materjal pärineb Lõuna-Eestist Tartumaalt või Lõuna-Viljandimaa kihelkondadest. Võrtsjärve ümbruse lõunapoolsetest kihelkondadest, kõige tõenäolisemalt Tarvastust pärinevad teise anonüümse saatja (SKS, Eisen 453-454) 60 mõistatust. Eesti mõistatuste ettevalmistamise ajal oli probleeme kahe Jaan Lievoh saadetise päritolu määratlemisega. Hiiumaal Käinas sündinud ja Noarootsis kooliõpetaja ametit pidanud J. Lievoh kirjutab 27. septembril 1887, et on Hiiomaalt ja Noarootsist korjatud (SKS, Eisen 151). 


\section{Rein Saukas}

Mõistatusi saadeti M. J. Eisenile 45 kihelkonnast (vt kaart 1). Kaardil on Jaan Lievoh Noarootsi või Hiiumaa mõistatused näidatud Noarootsi kihelkonna juures, tähistamata on Friedrich Wilhelm Ederbergi täpsema määratluseta Saaremaa korjandus, Johannes Bracksi oma Peterburist ja ilma kohaandmeteta saadetised. Kui võrrelda antud kaarti kaardiga 2 (varem ilmunud Krikmann 2000), näeme, et M. J. Eisenile on mõistatusi saadetud valdavalt nendest kihelkondadest, kust seda kogu kogumisloo on vältel rohkem tehtud.

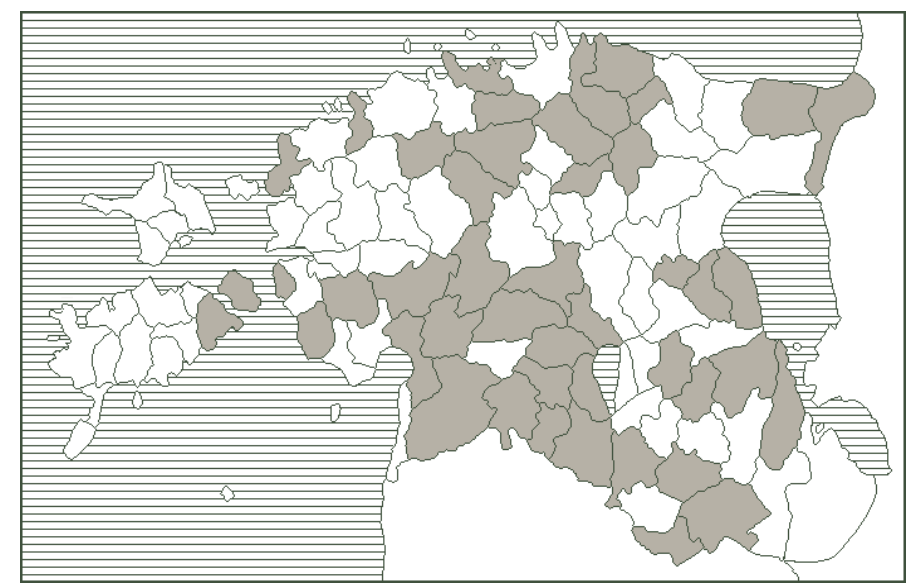

Kaart 1. Kihelkonnad, kust M. J. Eisenile mõistatusi koguti.

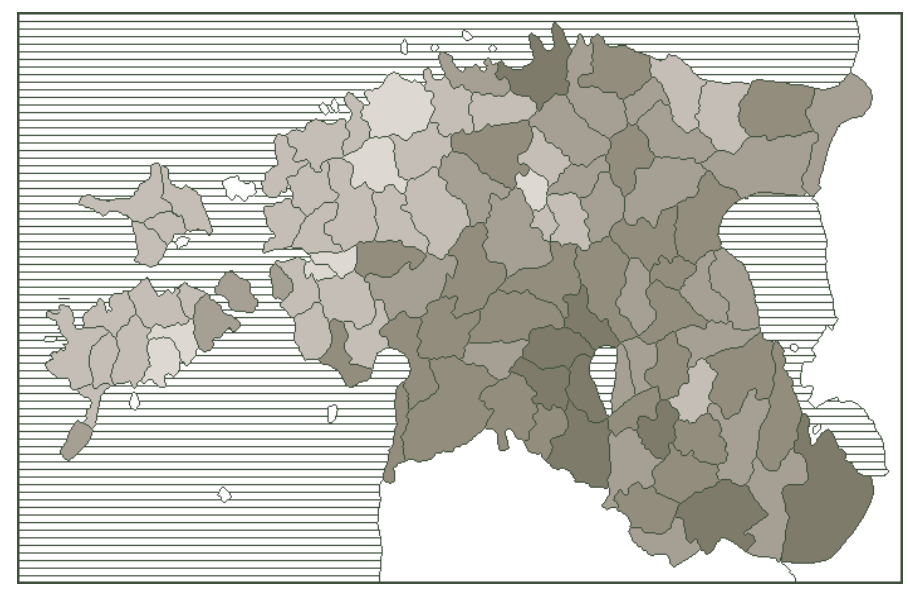

Kaart 2. Eestist kogutud mõistatuste hulk kihelkonniti. 


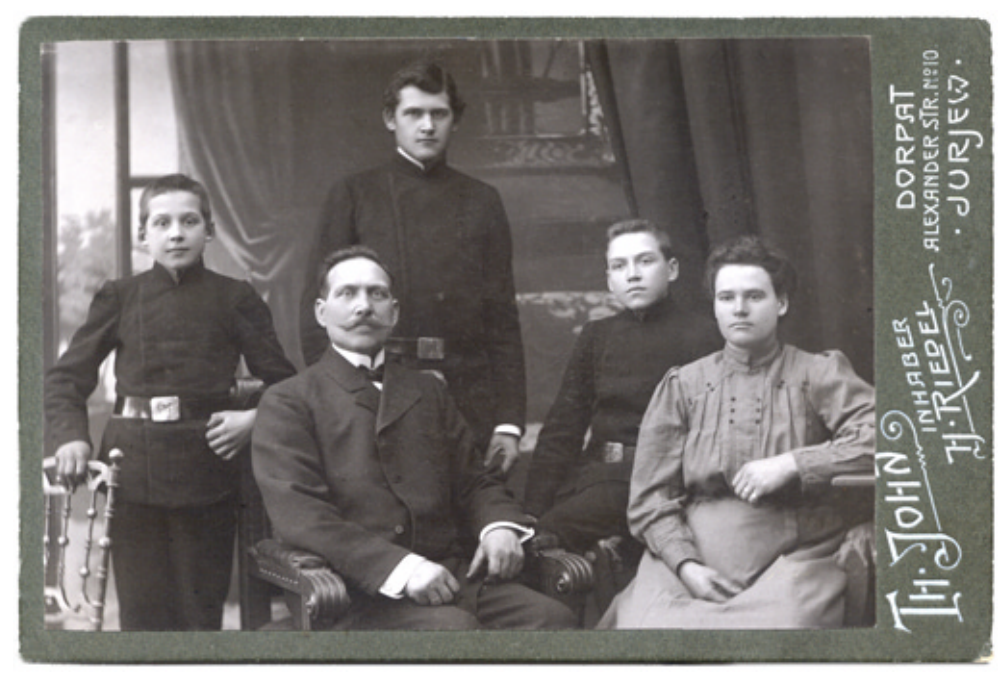

Foto 10. Jakob Puksov (1861-1946) perekonnaga u 1908. aastal. Abikaasa Juula, taga vasakult pojad Leo, Friedrich ja Artur. Theodor Johni \& Heinrich Riedeli foto (Tartu Ülikooli Raamatukogu käsikirjade ja haruldaste raamatute osakond, f 59, s 454: 1).

Isikuloolisi andmeid M. J. Eisen oma kaastöölistelt ülekutsetes ja aruannetes ei küsinud, tavaliselt neid ka ei lisatud. Ometi on mitmesuguste abimaterjalide toel võimalik koguda informatsiooni kaastööliste kohta. Lihtsamaks osutub asi siis, kui koguja on hiljem J. Hurdale kaastööd teinud või mingil alal tuntuks saanud.

Ometi õnnestus saada Matthias Johann Eiseni kaastööliste kohta kaudsete allikate abil üsna aukartust ärataval hulgal teavet. Järgnevas kogujate liigituses olen arvestanud elukutset või tegevust M. J. Eiseni kogumisaktsiooni aastatel, kuigi paljud jõudsid elu jooksul mitmes ametis olla. Kes siis olid M. J. Eiseni kaastöölised?

Kõige rohkem, peaaegu kolmandik oli kooliõpetajaid, kokku 20: A. G. Eriksohn, Mihkel Kampmann, M. Karotom, Timotheus Kuusik, S. Käär, Jaan Lievoh (1862-1935), Juhan Mein (1859-1912), J. Paap, Johann Pastarus (1850-1903), Jüri Peterson (1844-1907), Jakob Puksov (1861-1946), H. Redlich, Konrad Roost (sünd 1872), Heinrich Stein (1844-1904), Jüri Tilk, Tõnis Tilk, ${ }^{12}$ Jaan Valdt (18631933), Villem Kullerkupp (1859-1915), Hans Perkson (sünd 1862), Heinrich Tiidermann (1863-1904).

Kogumistöös lõid kaasa Tartu Õpetajate Seminari õpilased Johann Trull (1871-1940), Tõnu Sander (1868-1894), Nõo koolipoiss 


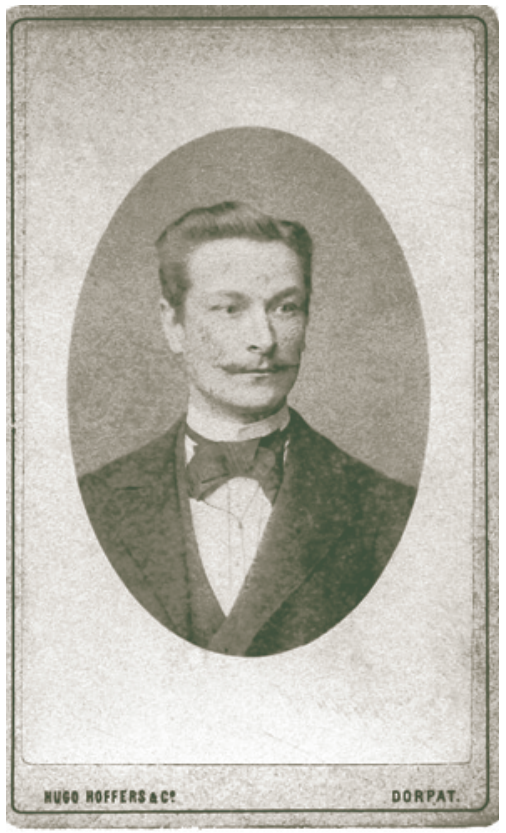

Foto 11. Julius Tiedemann (18551918). Hugo Hoffersi foto. Tartu (EKLA, A-71: 162).

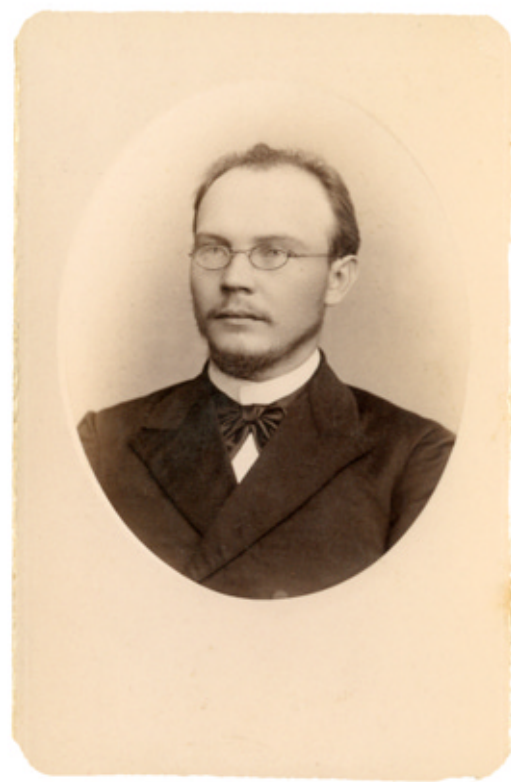

Foto 12. Kooliõpetaja Konrad Roost (sünd 1872). J. Steinbergi foto. Peterburi (ERA 9089).

(küla koolilaps (mai 1888; SKS, Eisen 412)) Voldemar Grünstamm (1876-1913?), koolipõlves tegi oma rahvaluule ülestähendused ka Julius Tiedemann (1855-1918).

Koolmeistrite kõrval olid arvukamalt esindatud põllumehed, neid oli seitse: Mihkel Kiisk (1861-1939), Johann Mägi (sünd 1870), Nigolas Otto (1862-1930), Aleksander Martin Saar (sünd 1866), Mart Tamm, Jaak Toss (sünd 1867), Hans Utso.

Veel oli kogujate hulgas järgmisi ametimehi: raudtee telegraafiametnik, vallakirjutaja Carl Martin Redlich (1853-1896), metsavaht Jaan Leppik (1861-1943), vabatahtlikuna aega teeniv soldat Peäro August Pitka, mõisa toapoiss Jüri Reinson, Kaiavere mõisa piimavedaja Gustav Tenter (1864-1910), ehitusmeister Toomas Tetsmann (sünd 1854), vallakirjutaja Peeter Ruubel (1868-1932), üliõpilased Joosep Hurt (1855-1888; Jakob Hurda lellepoeg) ja Jaan Miländer. Õrnema poole esindajaid lõi kogumistöös kaasa kolm: M. Falk, taluperenaine Helene Maasen (1869-1933) ja Elisabeth Aspe (1860-1927). 


\section{Rein Saukas}

Neid kogujaid, kelle elukutse või amet on jäänud teadmata, on 23: Juhan Aab, Johannes Bracks, M. Falk, H. R-e, Nicolai Jegorov, Karl Kirschbaum, Jakob Koit, Jaan Kripson, Jaan Lambert, A. Martson, M. Oiderman, K. Pedak, J. Pikkel, A. Redlich, Jakub Reial, Sööt, Mihkel Tilk, Peeter Unt ja Joh. Voites. Anonüümseks on jäänud neli isikut (üks Harglast, üks Rõugest ja kaks teadmata päritolu).

Kohalikud rahvaluulekogujad olid tavaliselt ärksa vaimuga ja haritud noored (teadaolevate sünniaastate järgi arvestades umbes 25 -aastased) inimesed, kellest nii mõnigi sai hiljem eesti kultuuriloos tuntuks. M. J. Eiseni mõistatuste kogumisaktsiooni kaastööliste hulgas olid hilisem kirjanik Elisabeth Aspe, kirikuõpetaja, tõlkija ja kultuuriloolane Friedrich Wilhelm Ederberg (1859-1939), koolikirjanik ja kirjandusloolane Mihkel Kampmann (1867-1943), lastekirjanik ja tõlkija Timotheus Kuusik (1863-1940), luuletaja ja tõlkija Jaan Leppik (1861-1943), arst ja Tartu ülikooli õppejõud Jaan Miländer (1866-1940), proosa- ja näitekirjanik Peäro August Pitka (pseudonüüm Ansomardi; 1866-1915), luuletaja Carl Martin Redlich (1853-1896), kirjandusloolane Tõnu San-

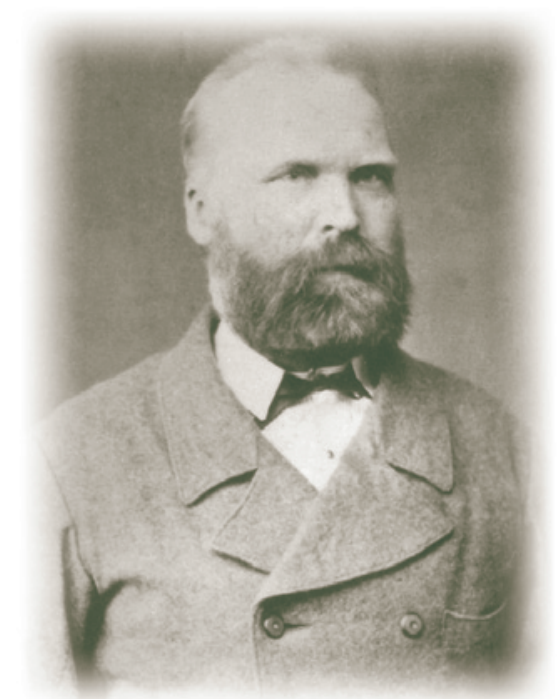

Foto 13. Kooliõpetaja Jüri Peterson (1844-1907). J. Livenströmi foto enne 1886. Viljandi (EKLA, A-91: 1).

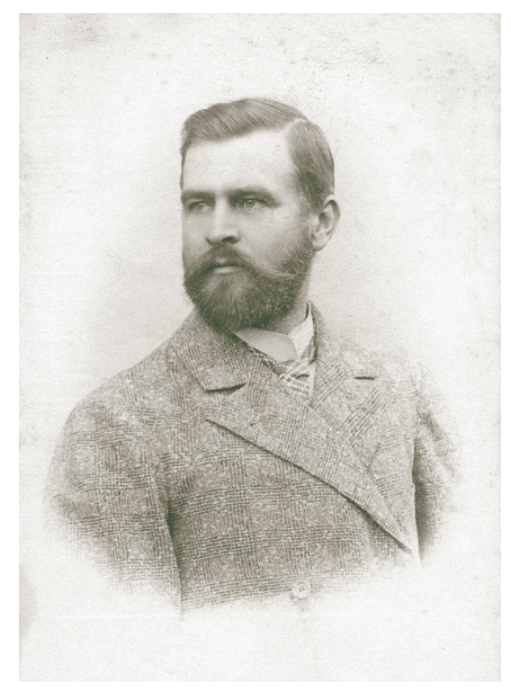

Foto 14. Kooliõpetaja, hilisem trükkal ja fotograaf Heinrich Tiidermann (1863-1904) (EKLA, A-14: 18). 


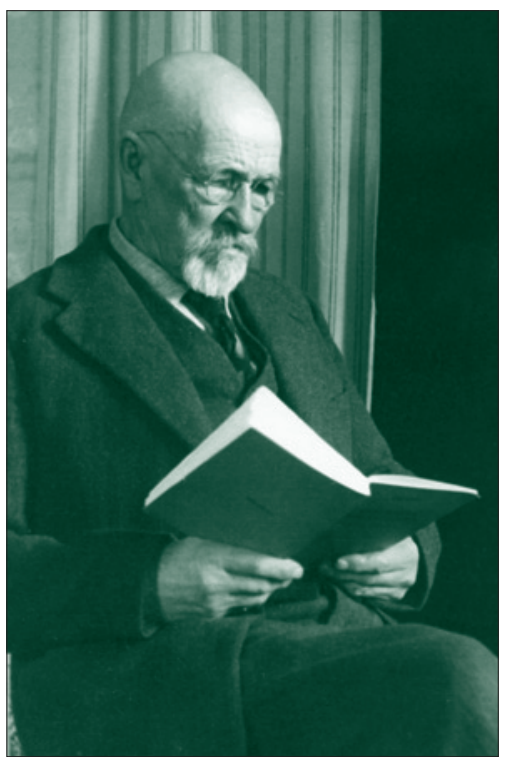

Foto 15. Pôllumees Aleksander Martin Saar (sünd 1866) 10. aprillil 1938 (EKLA, A-2: 2097)

der (1868-1894), trükkal ja fotograaf Heinrich Tiidermann (18631904) ning karskustegelane ja ajakirjanik Jüri Tilk (1865-1929).

M. J. Eiseni kogumisaktsiooni kaastöölised olid haritud, hea või väga hea kirjaoskusega (teistega võrreldes tundub veidi abitu olevat anonüümse saatja SKS, Eisen 449-451 käekiri), kõik saadetised on korrektselt vormistatud ja hästi loetavad. Peale mõne üksiku (Jakob Puksov Räpinast, Jaan Kripson Võnnust, Jakub Reial Kolga-Jaanist, S. Kääri Kodaverekorjandus, anonüümne koguja SKS, Eisen 427-431) on mõistatused üles kirjutatud kirjakeeles mõningaid murdevorme ja/või murdesõnu kasutades, ette tulevaid tundmatuks jäävaid sõnu on vahel seletatud, paaril kogujal (näitK. Pedak) on täheldatav vana kirjaviisi vähene mõju. Polnud ju juhendaja lisanud nõuet murdekeele jälgimiseks - seda ei pidanud M. J. Eisen ilmselt vajalikuks.

\section{Autentsusolud säilikus SKS, Eisen}

E. Normann on teinud oma intuitsioonile toetudes oletuse, et M. J. Eiseni esimene mõistatuste trükiväljaanne sisaldab ebarahvapärast ainestikku, kirjanduslikke ja kogujate omatehtud mõistatusi umb. 5-7\% (Normann 1961: 424).

Praegu, kui kogu M. J. Eiseni kogumisaktsiooni käigus laekunud materjal on rahvaehtsuse seisukohalt detailselt ja põhjalikult läbi sõelutud, võib üldistavalt öelda, et antud materjal on suhteliselt autentne. 67 kaastöölisest 51 materjalile saab anda kas hea või väga hea hinnangu, nende puhul ei ole tuvastatud trükiallikate kasutamist. Kirjanduslikest allikatest pärineb või on omaloominguks arvatud siiski 10,6\% käsikirjalisest materjalist (umbes 
600 teksti). Seda on küll rohkem, kui Erna Normann oletas, kuid tunduvalt vähem, kui meie mõistatuste üleskirjutustes tervikuna $(33 \%)$.

Mõningaid kahtlusi on tekitanud J. Koidu alfabeeti pandud korjandus, mille puhul on põhjust arvata, et kogujal oli meelde jäänud erinevates Eesti Rahva Kalendri aastakäikudes avaldatud mõistatusi. Friedrich Wilhelm Ederberg on tuttav olnud C. E. Mötleja Mõistatuste raamatuga, anonüümne saatja (SKS, Eisen 453-454) aga Jaan Liivi Laste Mängu-toaga. Ka Jaan Jaaksonil ja Jaan Leppikul kui haritud meestel on mõnestki mõistatusi sisaldanud väljaandest (F. J. Wiedemanni Aus dem inneren und äusseren Leben der Ehsten, ajakiri Meelejahutaja (1887)) ühte ja teist meelde jäänud. Nimetatud kogujate puhul ei ole niisiis tegemist trükistest mahakirjutajatega, vaid nende / informantide mõistatuste repertuaar on olnud mõjustatud hiljuti ilmunud trükisõnast. Kuid siin ei saa kõnelda veel sekundaartraditsioonist, mida rahvaluule lühivormide puhul arvukalt ette tuleb, sest trükistes ilmunu ja nimetatud kirjapanekute vahele jääb väike ajavahemik.

Iseloomustame sellist juhust J. Jaaksoni korjanduse 264. mõistatuse Suu suitseb, habe väriseb? Saag näitel (EM 2042). Tüübi vanim tekst on H. Gösekeni grammatikas leiduv mõistatusetaoline Suu suitseb, habe väriseb, lõuad lodisevad, hambad kärisevad? Singer, mille avaldavad F. J. Wiedemann ja M. J. Eisen oma raamatutes, hiljem ilmub see ka arvukates kooliõpikutes. Kõik arhiiviüleskirjutused peale J. Jaaksoni on trükiallikatest otseselt maha kirjutatud. Seega saab ka J. Jaaksoni üleskirjutus lähtuda kuidagimoodi ainult ja ainult F. J. Wiedemanni raamatust - lugemisel mõistatuse osaline meeldejäämine, raamatu lehitsemine saadetise kolmenädalase kirjapanemise ajal jms. Igatahes on selge, et rahvasuus kõne all olev mõistatus küll ei käibinud.

F. W. Willmanni Juttud ja Teggud... kui populaarne rahvaraamat osutus kõige sagedasemaks kopeerimisallikaks. Seitse M. J. Eiseni kaastöölist - Hans Perkson, Johann Trull, Toomas Tetsmann, A. Martson, Elisabeth Aspe, Hans Utso, Helene Maasen (kasutab siiski F. W. Willmanni algallikat, s.o A. T. Helle grammatikat) -, on sealt, kes vähem, kes rohkem, mõistatusi ümber kirjutanud. H. Maasenil on ainult viis trükisevälist teksti, E. Aspel veel vähem - kaks. H. Utso Tarvastust on alustuseks kirjutanud oma saadetisse $4 / 5 \mathrm{~F}$. W. Willmanni raamatus toodud mõistatustest, siis teinud otsustava pöörde ja hakanud üles märkima väga head kohalikku repertuaari. A. Mart- 


\section{Rein Saukas}

sonil ja T. Tetsmannil mõlemal on ka autentset materjali, kusjuures viimane kirjutab "jälgede segamiseks" korjanduse lõppu: Meie oma küla maalt kokku korjanud Vändras (SKS, Eisen 190).

Kummalisel moel on Eisen kirjutanud H. Steini korjandusele märkuse: Palju omatehtud mõistatusi?? (SKS, Eisen 76), jätnud aga hoopis tähele panemata Carl Martin Redlichi ja J. Bracksi saadetised, mis rahvapärast materjali peaaegu ei sisaldagi. Luuleandeline C. M. Redlich suutis M. J. Eiseni täielikult ära petta, tootes viimasele just niisugust repertuaari, mida see ootas - tekste, mida varem polnud saadetud. Tema saadetud 77 mõistatusest on andmebaasis folkloorseks loetud vaid 18, ülejäänud on kõik kas Kasulisest Talurahva Kalendrist (1883) maha kirjutatud või koguja omalooming. Siinkohal siis näiteid selle viljaka looja toodangust:
Alta otsa risti-rästi, keskel körti, peala vetta, kõik kolm naga- tagused? Taaritôrs (EM 34);
Hilp ees, tallukas taga, lippi-lappi liperdis? Hernehirmutis (EM 227);
Hüppab kui hiir, kargab kui kass, kilkab kui kilk? Rohutirts (EM 310);
Kits kullitab, laps lullitab? Luitu- või sikusarv (EM 683);
Mees mauli maas, naine selili seljas, kõht körti täis? Leivaküna (EM 1100);
Noorik niidul, vai sees, mätas mütsiks peas? Heinakuhi (EM 1472);
Punane pull, seest sappi täis? Jõhvikas (EM 1734);
Viht vitsata, luud lehita, tort takuta? Habe (EM 2514) jne.

Peterburi korrespondent Johannes Bracks, kes pärines Hanila kihelkonnast, saatis aga hoopis imelikke mõistatusi:

Ma olen üks vana mees, olen 12 poega sünnitand, nendel on 30 tütarlast, kes pool valged ja pool mustad sündind. Ühesugune vari ja mõte.

Mina ja pojad ja onklid ei sure ja ei lähe ka vanemaks? Aasta ja 12 kuud ja need päävad.

Ma olen vormis ümmargune, läbipaistav, ilus, kirju. Üks tasa ôhk mind sünnitab, üks kange õhk mind kautab? Ülespuhutud seebivaht.

Kas need on omalooming või mõnest võõrkeelsest raamatust tõlgitud, pole õnnestunud välja selgitada. J. Bracksi mõistatused on ise- 
gi M. J. Eisenile paistnud ebatraditsioonilised ja ta pole neid oma väljaandesse paigutanud.

Carl Martin Redlichi ja J. Bracksi kõrval on lausa imeteldav Peäro August Pitka aus ülestunnistus kahe omaloomingulise moodustise kohta - ühele mõistatusele lisab ta kommentaari Rahva mõistatuse järele PAP, teisele Vene rahva mõistatuse järele PAP (SKS, Eisen 67). Pitka luulelduse Ümmargune, vöödiline, / ise ümbert karvane. / Juhtub häda, äpardusi, / veereb tilgal temast vesi? Silm eeskujuks on olnud vene mõistatus Cтоит хата - / кругом мохнато, I придет беда - / и потечет вода.

\section{Käsikirjade saatus}

Mis puutub mõistatuste käsikirjadesse, siis ei hoolinud M. J. Eisen nende hoidmisest enda valduses - olid ju kõik talle vähegi huvi pakkunud variandid raamatus trükitud. Ta saatis oma kaastööliste abiga kogutu kasutamiseks Kaarle Krohnile ja nagu selgub tema 20. aprillil 1892 kirjutatud kirjast, ei soovinudki neid tagasi: Laulude tagasisaatmisega ruttu ei ole; esiotsa ma nendega ju midagi ei tee. Veel vähem ruttu on mõistatustega; võid neid nii kaua enda käes hoida, kui ise tahad. Sama mõtet kordab ta veel 7. detsembri kirjas.

1893. aasta algul otsustab M. J. Eisen kinkida käsikirjad K. Krohni vahendusel Soome Kirjanduse Seltsile, mille kirjavahetajaliige ta oli. Tsiteerigem veel kord kirjavahetust, täpsemalt M. J. Eiseni kirja K. Krohnile 3. jaanuarist 1893:

Ma mõtlen, et minu rahva mõistatusi ei olegi tarvis tagasi saata. Ma olen need kõik ju trükkida lasknud ja Sina jälle oled nende kohta teaduslikku tööd teinud. Ma arvan, et ehk kõige parem, kui nad Kirjallisuuden Seuralle kingituseks saavad antud. Mis sa arvad selle kohta? Kui sa sellega nõus oled, siis võid Sa kõik need mõistatused kohe Kirjallisuuden Seura arhiivi viia. - Ma arvan, et mul siin kodu niisama suur mõistatuste uus kogu on kui see, mis sinu käes.

Üleandmist kinnitab ka Eesti ajakirjandus (Postimees, 22. veebruar 1893). Annetus on registreeritud Soome Kirjanduse Seltsi (SKS; Suomalaisen Kirjallisuuden Seura) protokollis 16. märtsist 1893, kust loeme: Käsikirjoituskokoelmiin [---] on pastori M. J. Eisen 


\section{Rein Saukas}

Kroonlinnassa lahjoittanut arvokkaan kokoelman virolaisia arvoituksia (Suomalaisen Kirjallisuuden Seuran keskustelemukset 1892-1893: 119).

Ometi tõuseb mõistatuste andmine SKSile uuesti avalikkuse tähelepanu alla 1932. aastal seoses Oskar Looritsa (M. J. Eiseni arvates) ilmselt eksliku või pahatahtliku väitega (Viidebaum \& Loorits 1932: 214), et M. J. Eisen käsikirjad Soome olla müünud. Asjaosaline ise avaldab Eesti Kirjanduses seletuse:

Õpetatud Eesti Seltsi poolt väljaantud "Vanavara vallast" on 214. leheküljel tähendatud, et mina mü̈̈nud omal ajal Soome Kirjanduse Seltsile üle 5000 mõistatise teisendi. Selle väite kohta olgu öeldud, et ma oma "Eesti mõistatustes" äratrükitud mõistatiste käsikirju olen Soome Kirjanduse Seltsile soome sellekohaste ainete vastu $v$ ahe ta $n u d$, aga mit te m ü̈̈ n ud [Eiseni sõrendused - R. S.] (Eisen 1932: 528).

1931. aasta 7. oktoobri otsusega andis SKS M. J. Eiseni mõistatustekogu Eesti Rahvaluule Arhiivile. Üleandmiskirjas iseloomustatakse materjali järgmiselt: $\underline{M}$. J. Eisen. Kl. n:o 12726, kaksi koteloa, sisältävä virolaisia arvoituksia, jotka ovat kirjoitetut erikokoisille papereille. (Eri lähettäjäin kokoelmia.) (EFAM, ERA, M.1A.)

Matthias Johann Eiseni kogumisaktsiooni materjalid asuvad praegu Eesti Rahvaluule Arhiivi rahvaluulekogus ühes kvartformaadis köites, mis kannab ENSV TA Riikliku Kirjandusmuuseumi rahvaluuleosakonna inventarinumbrit 761. Säilikut tsiteeritakse šifriga SKS, Eisen. Eiseni põhikogus asub vaid J. Tiedemanni saadetis - E 128-163, 166-168. Kogus SKS, Eisen leidub peale mõistatuste veel üksikuid looma- ja kohanimede ülestähendusi ning kaastööliste kirju kogumistöö organisaatorile. Säilikus on 495 nummerdatud lehekülge, neile eelneb viis nummerdamata lehte, mille sisuks on tühjale lehele kleebitud Peeter Ruubeli saadetise ümbrik aadressiga M. J. Eisenile Kroonlinna, kolmel erineval kujul saatjate loend, üks M. J. Eiseni, kaks tõenäoliselt materjali korraldaja käekirjaga.

Saadetised on reastatud traditsioonilise kihelkondade ringi järgi. Esimesed on Carl Martin Redlichi korjandused Vaivarast, viimane Jakob Puksovi saadetis Räpinast. Järgnevad kohaandmeteta ja anonüümsed üleskirjutused ning köite lõpetab lehekülgedel 455-495 M. J. Eiseni koostatud Eesti rahva mõistatuste (töö)käsikiri. 


\section{Eesti rahva mõistatused (1889 [1890])}

Mõistatusteraamatu avaldamine ei läinud Matthias Johann Eisenil nii nobedasti, kui ta lootnud ja lubanud oli, eriti kui võrrelda varasematega, mida ta puistas nagu käisest. Kogumistöö algusest 1887. aasta septembris kuni Eesti rahva mõistatuste ilmumiseni 1890. aasta aprillis kulus neli kuud vähem kui kolm aastat. Siin võib põhjuseks olla mitu asjaolu. Esiteks, eespool kõne all olnud M. J. Eiseni enda elu ebastabiilsus neil aastail. Teiseks, järjest enam aega nõudev kogumistöö, mille sujuvamat korraldamist M. J. Eisen ise pidevalt õppis (oli ta ju siin alles algaja). Kolmandana ei saa nimetamata jätta ka raamatu sisulist mahukust - oli see ju üks esimesi nii põhjalikke ühe rahvaluuleliigi tekstipublikatsioone.

Et M. J. Eisen püüdis raamatut võimalikult ruttu välja anda, andis ta kaastöölistele ja ajalehelugejatele pidevalt aru mõistatusraamatu ettevalmistamise käigust. Tema esimene sellekohane notiits ([---] niisama ka Eesti vanu mõistatusi järjestanud) pärineb 16. novembril 1887 kirjutatud kirjast Kaarle Krohnile. Juba 1888. aasta märtsis on nõu olnud raamat trükki anda, aga kuna näis, et mõistatusi tuleb üha juurde, ei teinud ta seda (Eisen 1888b). Järgmisel kuul, 9. aprilli aruandes teatab M. J. Eisen: Kõik minu kätte saadetud mõistatused on juba trüki tarvis puhtaks kirjutatud ja abd järele ära jaotatud. Kokku on selleks ajaks olemas 1190 mõistatust: kõige enam $\mathrm{k}$-algulisi - 216, r-algulisi aga ainult 12 (Eisen 1888c).

Kaarle Krohnile valgustab ta 20. aprillil 1888 saadetud kirjas asjade käiku sootuks teistmoodi: Vanade Eesti mõistatuste väljaandmise kallal teen ka tööd, aga need ei ole ammugi veel mitte käsikirjas valmis ega tea ma praegu ütelda, mil nendega valmis jõuan. Sama aasta 29. novembril samale adressaadile kirjutatud kordas M. J. Eisen veel kord lubadust raamat peagi trükki anda: Eesti rahva môistatusi ei ole ma tänini veel trükki annud, olen veel korjanud, tahan aga nü̈̈d pea trükki anda.

Tsensor on andnud loa 1889. aasta 4. septembril, raamatu ilmumine viibis aga veel üle poole aasta. $\mathrm{K}$. Krohnile saadetud kirjadesse pudeneb aeg-ajalt raamatu väljaandmist puudutavaid teateid, kordagi viitamata protsessi venimise põhjustele. Praegu on minu rahva mõistatused trükis; umbes 600 mõistatust $=5$ trükipoogent on juba valmis trükitud, kirjutab ta 17. septembril 1889. Minu "Mõistatused" on ammu juba trükis, aga praegu ei tea ma ikka veel, millal nad ilmuvad. Umbes 3 poognat on veel trükkimata, annab M. J. Eisen sõbrale teada 21. veebruaril 1890. 


\section{Rein Saukas}

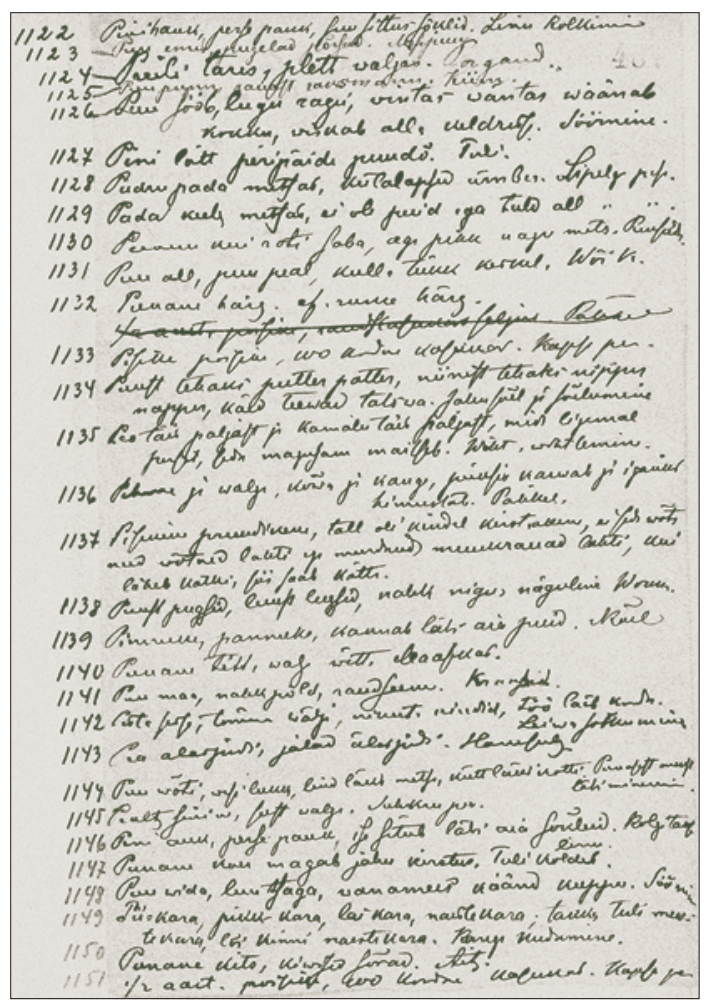

Foto 16. Matthias Johann Eiseni Eesti rahva mõistatuste töökäsikiri. Suvi 1888 (SKS, Eisen 487).

Raamatu koostamise viisist annab ülevaate (üks) säilinud, väljaande endaga mitte täpselt kattuv, tõenäoliselt 1888. aasta kevadel või suvel koostatud käsikiri, mis on paigutatud säiliku SKS, Eisen lõppu lehekülgedele 455-495. Käsikirjalehed M. J. Eiseni käekirjas sisaldavad 1218 nummerdatud mõistatust. Tegelikult on materjali 1216 punkti, sest vahepeal puuduvad numbrid 291-299 ja 954-955, samas on üheksal juhul kasutusele võetud tähis $a$. Läbiv numeratsioon on tõenäoliselt hilisem (kas materjali korraldajalt?), M. J. Eiseni käega pliiatsikirjas pandud numbrid on lihtsalt üle kirjutatud.

SKS, Eisen 455-495 leiduv aines on väljakirjutused kaastööliste saadetistest ja trükiallikatest mõistatuste esitähtede järgi. M. J. Eisen on väljakirjutusi teinud eri formaadis lehtedele, mistõttu köitmisel ei ole käibivast alfabeedist saanud kinni pidada, samuti ei ole 
kõik ühe ja sama algustähega mõistatused mahtunud ühele lehele ja on sattunud köitmisel erinevatesse kohtadesse. Materjali järjestus mõistatuste esitähtede järgi ja maht on järgmine: M (1-36), I(37-82), A (83-109), E(110-151), H(152-242), N (243-286), T (287-374), $\mathrm{M}$ (375-449), L (450-522), S (523-603), R (604-615), P (616-631), O, Õ, Ö (632-654), V (655-743), U, Ü (744-808), K (809-962), P(963-1040), K(1041-1076), M (1077-1121), P (1122-1151), K(11521180), V(1181-1185), S(1186-1194), P (1195-1215), varia (1216-1218).

Eiseni põhimõttest antud käsikirja kokkupanemisel annab ülevaate järgmine tabel, mis jälgib $v$-algulisi mõistatusi.

Tabel 1. V-alguselised mõistatused käsikirjas SKS, Eisen 455-495

\begin{tabular}{|c|c|}
\hline $\begin{array}{l}\text { Teksti nr } \\
\text { käsikirjas }\end{array}$ & $\begin{array}{l}\text { Aluseks olnud trükised, } \\
\text { käsikirjad }\end{array}$ \\
\hline 655 & C. M. Redlich, SKS, Eisen 3-5 (55) \\
\hline $656-658$ & $\begin{array}{l}\text { F. J. Wiedemann. Aus dem inneren..., } \\
\text { lk } 293\end{array}$ \\
\hline $658 \mathrm{a}$ & C. M. Redlich, SKS, Eisen 3-5 (56) \\
\hline $659-680$ & $\begin{array}{l}\text { F. J. Wiedemann. Aus dem inneren..., } \\
\text { lk 293-294 }\end{array}$ \\
\hline $681-682$ & $\begin{array}{l}\text { C. E. Mötleja. Mõistatuste raamat, } \\
\text { nr 137, } 139\end{array}$ \\
\hline 683 & C. M. Redlich, SKS, Eisen 3-5 (57) \\
\hline $684-689$ & $\begin{array}{l}\text { C. E. Mötleja. Mõistatuste raamat, } \\
\text { nr 141-144, 146-147 }\end{array}$ \\
\hline $690-697$ & $\begin{array}{l}\text { M. J. Eisen, SKS, Eisen 121-135 } \\
(39,19,21,47,53,57,60,136)\end{array}$ \\
\hline $698-699$ & C. M. Redlich, SKS, Eisen 3-5 $(29,26)$ \\
\hline $700-702$ & $\begin{array}{l}\text { M. J. Eisen, SKS, Eisen 121-135 } \\
(25,24,2)\end{array}$ \\
\hline $703-709$ & $\begin{array}{l}\text { E. Lönnrot. Suomen kansan } \\
\text { arvoituksia ... 1851, nr 1918, 1926, } \\
\text { 1938, 1946, 1949, 1978, } 1977\end{array}$ \\
\hline $710-711$ & Alustekst teadmata \\
\hline $712-713$ & Meelejahutaja 1887 \\
\hline
\end{tabular}




\section{Rein Saukas}

\begin{tabular}{|l|l|}
\hline $714-715$ & Alustekst teadmata \\
$716-720$ & J. Lievoh, SKS, Eisen 151-156 \\
& (18, 35, 41, 68, 83) \\
$721-722$ & S. Käär, SKS, Eisen 361-364 (8, 12) \\
723 & C. M. Redlich, SKS, Eisen 3-5 (63) \\
724 & S. Käär, SKS, Eisen 361-364 (51) \\
$725-726$ & Alustekst teadmata \\
727 & P. Unt, SKS, Eisen 413-416 (61) või \\
728 & V. Grünstamm, SKS, Eisen 409-412 (11) \\
729 & Alustekst teadmata \\
730 & J. Lambert, SKS, Eisen 141 (4) \\
$731-734$ & Sööt, SKS, Eisen 399 (1) \\
& Anonüüm, SKS, Eisen 435-436 \\
$735-738$ & (1, 7, 8, 14) \\
$739-740$ & J. Paap, SKS, Eisen 425-426 \\
$741-742$ & (5, 34, 38, 50) \\
743 & J. Tilk, SKS, Eisen 247-250 (11, 56) \\
$1181-1182$ & J. Peterson, SKS, Eisen 181-184 (84, 85) \\
$1184-1185$ & Anonüüm, SKS, Eisen 453-454 (57) \\
& H. Perkson, SKS, Eisen 143-149 (10, 60) \\
& J. Reial, SKS, Eisen 353-356 (18, 35) \\
\hline
\end{tabular}

Antud käsikiri sisaldab $95 v$-algulist mõistatust, väljaandes leidub neid hoopis rohkem - 144 .

Vähemalt $r$-algusega mõistatuste puhul tundub käsikiri vastavat 1888. aasta 9. aprilliks laekunud materjalile (vt Eisen $1888 \mathrm{c}$ ja varasemad aruanded). Lähem tutvumine nende $r$-alguliste mõistatustega, mis esinevad väljaandes, aga puuduvad käsikirjas, näitas, et M. J. Eisen on kasutanud nende kaastööliste materjali, kes panid oma saadetised posti hiljem kui aprillis, nt Jaan Kripson, Aleksander Martin Saar, S. Käär jt. Kui ta koostas trükisele veel ühe käsikirja, siis pole see meieni jõudnud.

Nagu ülaltoodud tabelist nähtub, kasutas M. J. Eisen Eesti rahva mõistatuste koostamisel lisaks vabatahtlike kaastööliste saadetistele oma noorpõlvekäsikirja 1869. aastast, eesti mõistatusi sisal- 
davaid trükiseid ja, mis kõige hämmastavam, E. Lönnroti mõistatuste väljaande soome mõistatuste osa, tõlkides sealt allikale viitamata valikuliselt tekste eesti keelde, pakkudes niimoodi soome mõistatusi eesti omade pähe. ${ }^{13} \mathrm{E}$. Lönnroti tõlkemõistatusi on käsikirjas 141, seega üsna suur hulk. Järgnev tabel annab pildi M. J. Eiseni sellekohasest mugandamismetoodikast.

Tabel 2. Matthias Johann Eiseni Eesti rahva mõistatuste käsikirjas (SKS, Eisen 455-495) leiduvad tõlked Elias Lönnroti Suomen kansan arvoituksiast (Helsinki 1851)

\begin{tabular}{|c|c|}
\hline $\begin{array}{l}\text { Mõistatuse lk ja nr } \\
\text { ning tekst Lönnroti teoses }\end{array}$ & $\begin{array}{l}\text { Mõistatuse nr ja tekst } \\
\text { Eiseni käsikirjas }\end{array}$ \\
\hline $\begin{array}{l}141 \text { (1918): Valkiat kanaset } \\
\text { punaisella orrella? } \\
\text { Hampaat ja ikenet }\end{array}$ & $\begin{array}{l}\text { 703: Valged kanad puna } \\
\text { sel orrel? Hammad }\end{array}$ \\
\hline $\begin{array}{l}142 \text { (1926): Vanha vaari tuvassa } \\
\text { istuu, sata haava päässä? } \\
\text { Ruhmu, pölkky, hakkuri }\end{array}$ & $\begin{array}{l}\text { 704: Vanamoor toas, sada } \\
\text { haava peas? Palgiots }\end{array}$ \\
\hline $\begin{array}{l}143 \text { (1938): Vedessä seisoo, } \\
\text { maalla kaatuu? Verkko }\end{array}$ & $\begin{array}{l}\text { 705: Vees seisab, maas ei } \\
\text { seisa? Võrk }\end{array}$ \\
\hline $\begin{array}{l}\text { 143 (1946): Vesi alla, nahka } \\
\text { päällä, kylkiluut nahankin } \\
\text { päällä? Juomatynnyri; Vene }\end{array}$ & $\begin{array}{l}\text { 706: Vesi all, nahk peal, } \\
\text { küljekondid kõige peal? } \\
\text { Astja }\end{array}$ \\
\hline $\begin{array}{l}144 \text { (1949): Vesinen lukko, pui- } \\
\text { nen avain? Joki ja silta eli vene }\end{array}$ & $\begin{array}{l}\text { 707: Veest lukk, puust } \\
\text { vôti? Sild }\end{array}$ \\
\hline $\begin{array}{l}146 \text { (1978): Viisi veljestä edel- } \\
\text { lä menee, paljaspää takaa } \\
\text { ajaa? Varpaat ja kantapää }\end{array}$ & $\begin{array}{l}\text { 708: Viis venda lähevad } \\
\text { ees, paljaspea tagajärel? } \\
\text { Varvad,kand }\end{array}$ \\
\hline $\begin{array}{l}\mathbf{1 6 4} \text { (2208): Varas aittaan } \\
\text { menee, pussinsa portaille } \\
\text { heittää? Nuppineula }\end{array}$ & $\begin{array}{l}\text { 709: Varas läheb aita, } \\
\text { jätab koti välja? Nööpnõel }\end{array}$ \\
\hline $\begin{array}{l}165 \text { (2212): Viisi veljestä ve- } \\
\text { tä̈̈ yhtä vaivaista kahdesta } \\
\text { ovesta ulos? Nenän } \\
\text { niistäntä }\end{array}$ & $\begin{array}{l}\text { 710: Viis venda viskavad } \\
\text { kaks viletsat (tõbist) toast } \\
\text { välja? Nina nuuskamine }\end{array}$ \\
\hline
\end{tabular}




\section{Rein Saukas}

Kuigi K. A. Hermanni kulu ja kirjadega trükitud Eesti rahva mõistatused kannab tiitlil ilmumisaastat 1889 , jõudis see lugejate kätte alles järgmise aasta aprillis, nagu nähtub M. J. Eiseni 28. aprillil 1890 saadetud kirjast K. Krohnile: "Eesti rahva mõistatused" on nü̈̈d viimaks trükist ilmunud. Saatsin sulle mõne päeva eest ühe eksemplari, ju vist kätte oled saanud.

Eesti rahva mõistatuste tutvustuseks ilmus Postimehes K. A. Hermanni kiitev kirjutis, ülistussõnu lausus ta ka Eesti Kirjameeste Seltsi korraldatud "eesti parema kirjanduse ja kunsti IV suurel võidupeol” 22. juunil. K. A. Hermann iseloomustab raamatut niimoodi:

See mõistatuste kogu on suurem kui ükski teine enne teda. Täitsa 1770 mõistatust on raamatust leida. Kõik on rahva suust korjatud ja on hulk korjajaid raamatu kallal tööd teinud, sest nagu teada, on hr õp Eisenile suurem hulk neist kätte saadetud. Need mõistatused saavad iga mehe meele järele olema. Nad on nii tuumakad ja rahvuslised kui vähe võimalik. Ka on nende seas mõnigi, mis nii naljakas on, et naera kas katki. [---] Raamat on küll väärt, et teda rohkesti tähele pandaks (Hermann 1890: 1; vt ka Postimees, 26. juuli 1890).

Sootuks kriitilisemalt suhtub Eesti rahva mõistatustesse veel 12 aastat hiljemgi M. J. Eiseni sõber Kaarle Krohn, kes kirjutab:

Sellel kogul puuduvad ühe ja sama mõistatuse variantide kohaandmed nagu ka variantide täielik loetelu. Oleks tõsine ülesanne ühele eesti uurijale - korraldada ja kasutusele võtta peaaegu 50000 variandist koosnevat J. Hurda ja M. J. Eiseni eesti mõistatuste kogu (Krohn 1902: 77).

Formaadis 16x11 cm 181-leheküljeline, 1770 mõistatust, 10 mõistatuslaulu ja M. J. Eiseni saatesõna sisaldav väljaanne oli teine eesti mõistatusi sisaldav tervikraamat.

Lehekülgi 3-12 täitvas pealkirjata saatesõnas käsitleb M. J. Eisen mitut eesti mõistatuste ja käesoleva väljaandega seonduvat probleemi. Alustab ta eeposest Kalevipoeg, mille XVI loos päästab keeletark Lennuki meeskonna liikmed hiiglaste maalt etteantud mõistatusi nobedasti lahendades. Nimetatud Kalevipoja episood andvat tunnistust sellest, et rahva hulgas on mõistusest lugu peetud. Ka kosjadel pandavat peigmehele mõistatusi ette, et tema taibukust 


\section{Rein Saukas}

kindlaks teha. Edasi toob M. J. Eisen näiteid, kuidas mõistatusi lahendades omal ajal vangist pääsetud ja tsiteerib tekste:

Kivi õue toodi, süda sisse loodi, kelle tütar ma olen, selle emaks ma sain;

Tema minu isa, mina tema ema, keda ma imetan, on minu ema mees; Mure lind istub puuris, näeb kaks kolmat vedavat, kolm pääd ja kaheksa jalga (muinasjututüüp AT 928; vt Thompson 1964).

Eesti mõistatusi peab M. J. Eisen väga vanadeks, sest neil on teiste soome sugu rahvaste mõistatuste hulgas vasteid. Ühised on nimelt niisugused mõistatused, mis kudagi viisi meie hariduse ajalukku või looduse nähtustesse puutuvad, kirjutab M. J. Eisen (1889 [1890]: 7). Mõistatuste pikast east andvat tunnistust nende keeleline külg ja praeguseks ajaks tundmatud sõnad. $\mathrm{Sel}$ kombel juhtus aga ka kergelt, et need, kellel sõna tähendus võõraks jäänud, sõna ära väänasivad ja temale endisest kujust lahku mineva kuju andsivad. Seda näitavad mitme mõistatuse teisendid väga selgesti (Eisen 1889 [1890]: 7).

Järgnevalt teeb M. J. Eisen juttu väljaande tekstide valikuprintsiipidest. Ta on välja jätnud "nooremaid", s.t uuemaid, mida korjandustes ette tulevat, kuid mis olevat saksa keelest laenatud - toob näiteks F. J. Wiedemanni raamatus Aus dem inneren und äusseren Leben der Ehsten toodud tähemängu Ma olen üks lind... lahendusega $V a$ res, vars, varas. Kõrvale on

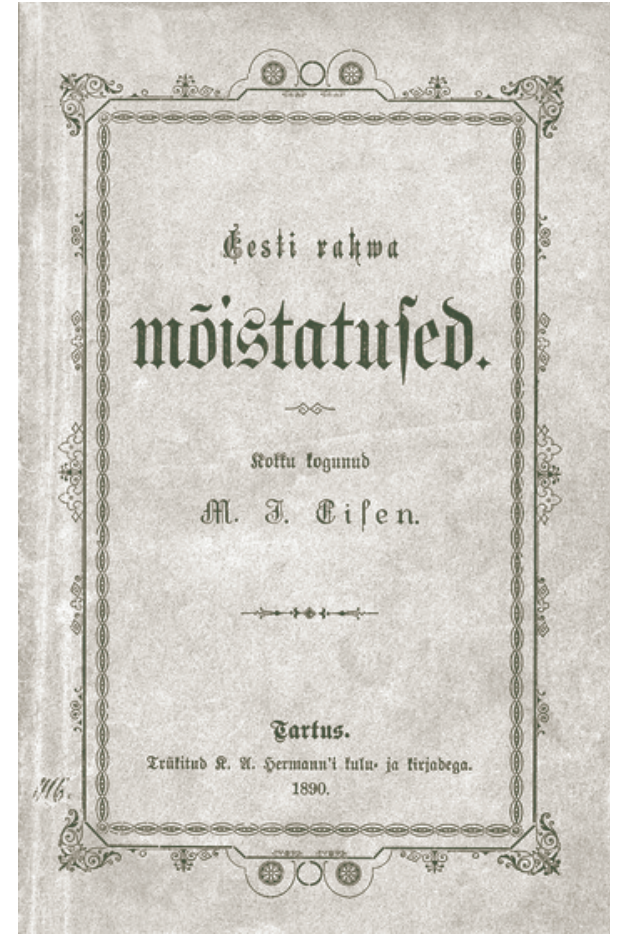

Foto 17. M. J. Eiseni Eesti rahva mõistatuste (1889) esimese trüki kaanel on kirjas raamatu tegelik ilmumisaasta 1890. 


\section{Rein Saukas}

ta heitnud ka F. J. Wiedemannil esineva teksti Mu süda mu seest on väänetud, mulle paljas nahk jäetud, mu suu on viltu lõigatud, mulle auk on selga tärgitud, ma vinnun toorelt tuule käes, ma kortsun kokku kuiva käes, kui mahla hakatakse jooma, siis minnakse mind metsast tooma (EM 1188), nagu ka keerdküsimused Mil sell meistri üle on? Kui sell teise ja meister alumise korra pääl tööd teeb ja Palju mune Koljat üsna tühja kõhuga ära sü̈̈a? Ühe.

Publikatsioonist jättis Eisen välja üksikud lahendusteta mõistatused, tuues kaks näidet: Kuuetahaline, kaheksakandiline, üheksaotseline, mille ta teises trükis siiski avaldab ja sellele isegi lahenduse odrapea leiab (EM 833); Örku-törku töllakille, sipa-sapa töllakille, viiru-kuuru töllakille? (EM 2598). Niisama pidivad hoopis kõlvatuma sisuga mõistatused kõrvale jääma. Päält näha kõlvatumad mõistatused, mis siiski kõlvatumat ei tähendanud, võeti korjandusesse vasta ((Eisen 1889 [1890]: 9).

M. J. Eisen iseloomustab eesti mõistatusi:

Terasemalt vanu Eesti mõistatusi tähele pannes leiame neid sügavasti järele mõteldud olevat. Mõistetavast antakse tavalisesti lühikesi omanduse kirjeldusi, mis tihti meelega hästi mitmekesiseks tehtud, et mõistmine seda raskem oleks. Mitmed mõistatused selle vasta ei tunnista mingisugust osavust. Sagedasti on lugu nii, et nende looja nende seletust ise ei oleks teada andnud, keegi seda puuduliku sisu pärast välja ei oskaks arvata (Eisen 1889 [1890]: 8-9).

Ta ütleb end hästi teadlik olevat, et raamatuke kõiki eesti mõistatusi, s.o mõistatustüüpe ei sisalda, aga ta pidanud paremaks raamatu siiski välja anda, et tulevased kogujad teaksid, missugused mõistatused on juba kogutud, missugused vajavad veel kogumist:

Korjanduse trükki andmisega loodan selle pärast korjajaid just agaramale korjamisele äratada. Käesolevas korjanduses näevad nad, missugused mõistatused juba üles kirjutatud ja missugused veel tarvis üles kirjutada (Eisen 1889 [1890]: 9-10).

Raamatu koostamisel aluseks olnud materjali loetledes nimetab M. J. Eisen kõigepealt oma 1869. aasta ülestähendusi, siis kõiki olulisemaid eesti mõistatusi sisaldanud trükiseid kuni aastani $1888 \mathrm{ja}$ 60 kaastöölise (loendis ohtrasti trükivigu) kogutud materjali. 
Rein Saukas

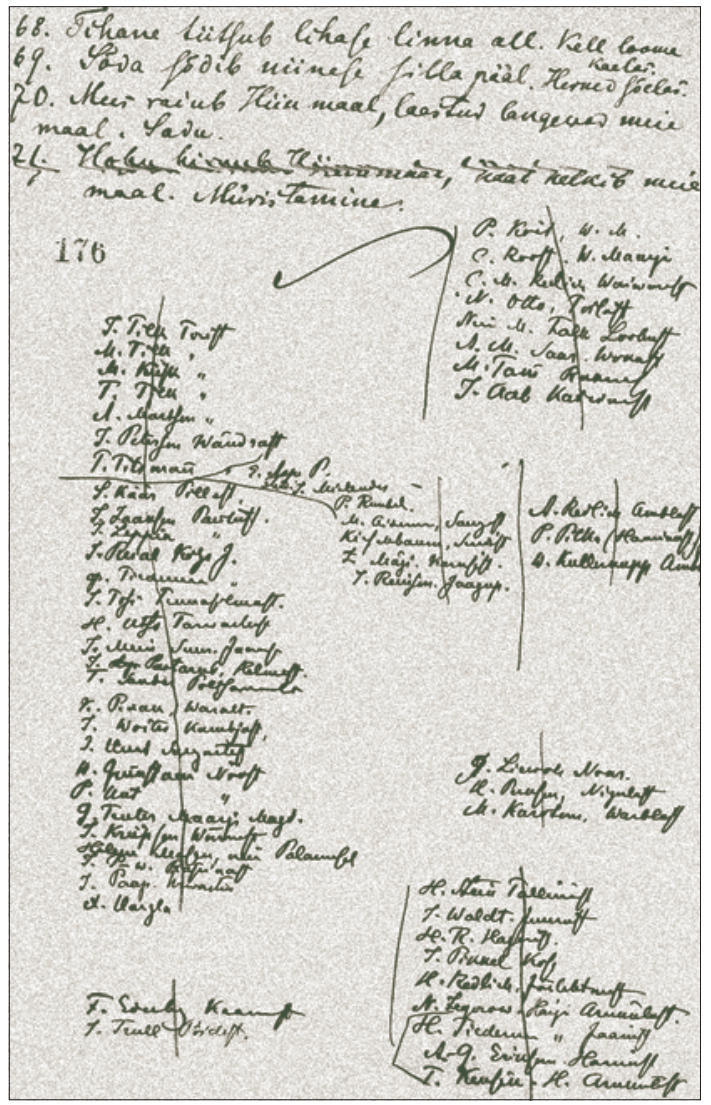

Foto 18. Matthias Johann Eiseni koostatud kaastööliste nimekiri Friedrich Wilhelm Ederbergi saadetise viimasel leheküljel (näide M. J. Eiseni suhtumisest käsikirjadesse) (SKS, Eisen 176).

Lõpuks selgitab ta, et mõistatused on esitatud raamatus alfabeetilises järjekorras ja mõistatusele on kohe lisatud lahendus. Mõistatusest olevat mitmeid teisendeid. Et kulukandja raamatut võimalikult väikseks ja hinda odavaks tahtis jätta, sellepärast olevat ainult kõige tähtsamad teisendid esindatud ja välja pidi jääma mõistatuste sisu järele valmistatud kättejuhataja, nagu ka teadusele tarvilikud seletused. Uurijatele jääb seega siis mõistatuste kodupaiga jne määramisel ainukeseks allikaks käsikirjade läbivaatamine (Eisen 1889 [1890]: 11-12). 


\section{Rein Saukas}

Kroonlinnas 1889. aasta jaanuarikuus koostatud saatesõna lõpeb üleskutsega: [---] kirjutatagu kõik veel puuduvad mõistatused ülesse ja saadetagu minu kätte, et meie rahva mõistatuste kogu täieliseks vôiks saada! (Eisen 1889 [1890]: 12).

Üldiselt on raamatus avaldatud mõistatused kohaandmeteta, kuid kümne mõistatuslaulu puhul annab koostaja viite nende päritolule, nimetades kahte trükist (M. Veske Eesti rahvalaulude I köidet ja H. Neusi Ehstnische Volkslieder'i III köidet) ning nelja kogujat: J. Tilka Torist (laulu originaal SKS, Eisen 207), F. Ederbergi (laulu originaal SKS, Eisen 173) ja J. Koppelit [Kappel] Saaremaalt ning O. Kallast Läänemaalt. ${ }^{14}$

Kuigi M. J. Eisen variante põhimõtteliselt oma väljaandesse ei tahtnud, on neid sinna ometi sattunud juba ülalpool kirjeldatud valikuprintsiibi tõttu. Illustreerigu seda kolm mõistatuste teadusliku väljaande tüüpi.

EM 1769: Niidist tehtud nipa-napa, puust tehtud pumbapamba, sõmarine rääskopp? Sõel, leivamõhk ja ahi (E EM 994); Niinest tehti nika-naka, puust tehti puka-paka? Sõel (E EM 995); Poger-pager puust tehtud, niger-nager niinest tehtud, sagaraud oli sauest tehtud? Tuba (E EM 1148); Puune pummerdi-nammerdi, niidsine nimmerdi-nammerdi, sõmerine rääsk? Leivamõhk, sõel, ahi (E EM 1203); Puust punder, niinest ninder, sauest sander? Leivalõime, sõel, ahi (E EM 1218); Puust puuliluulike, niinest nipsukepike, sauest tatsvaa, lükka sisse, tõmma välja, nikuta niuet, töö korras? Leivasõtkumine (E EM 1219); Puust tehaks puter-pater, niinest tehaks nipernaper, käed teevad tetsva? Jahusõel ja sõelumine (E EM 1222); Puust tehtud puka-paka, niinest tehtud nika-naka, sõmerine räätsik? Sõel (E EM 1223).

EM 1759: Peenike nagu rotisaba, aga pikk nagu mets? Puu süda (E EM 1084); Puu pikkune, pilliroo jämedune? Puu süda (E EM 1204); Teiste puude pikkune, õmbluslõnga jämedune? Puu süda (E EM 1436).

EM 2275: Käib niinesilda mööda, niinesillast raudakotti, raudakotist puupuhku, puupuhust nahkapauna, nahkapaunast ilma mööda laiali? Herned (E EM 399); Sada-sada, tuhat-tuhat jooksevad niinest silda mööda raudsesse linna? Herned sõelast patta (E EM 1269); Sõda sõidab rauast silda mööda? Herned pajas (E EM 1351); Sõjavägi läheb niinest silda mööda raudse linna? Herned sõelast patta (E EM 1355); Tirinaga-tärinaga 
raudsesse linna? Herneste patta panemine (E EM 1471); Tirrtirr teed mööda raudsesse linna, tulisesse merde? Herneste patta panemine (E EM 1472); Tuhat-tuhat, sada-sada jooksevad niinest silda kaudu raudsesse linna? Herned sõelast patta (E EM 1504); Tuhat-tuhat, sada-sada sõidavad niinest silda kaudu raudsesse linna? Herned sõelast patta (E EM 1504); Tuhat-tuhat, sada-sada tantsivad mööda niinest silda, langevad raudse haua põhja? Herned sõelast patta (E EM 1505); Valged lambad lähevad raudteed mööda merde mis kõrinal? Herned sõelast patta (E EM 1633).

Mida M. J. Eisen variantide ehk teisendite all täpselt mõtles, jääb paraku selgusetuks. Olid need sõna-sõnalt või enam-vähem sõnasõnalt kattuvad tekstid? Kogumistöö aruannetest jääb küll niisugune mulje. Väljaande eessõnas kõneldakse juba teisenditest, mida ka raamatus endas lähestikku üsna palju kohtab. Selge on, et arusaamisele iga üleskirjutatud variandi tähtsusest jõuab M. J. Eisen alles mõni aasta hiljem.

Matthias Johann Eisen ei osanud teha vahet kogujate omaloomingu ja rahvaehtsate mõistatuste vahel, seepärast on Eesti rahva mõistatustes üsna ohtrasti tekste, mille traditsioonilisust hilisemad üleskirjutused ei kinnita. Väljaandesse on sattunud ka niisugust ainest, mis ei ole mõistatused, nt vanasõna (vt EV 4532) Kuningal suur nagu heinakuhi, saab siia, ei mahu piipugi? Õigus (E EM 575).

Paarist tunnustavast tutvustusest olulisem on, et trükitud 1200 eksemplari jõudis rahva kätte ja omandas seal isegi teatava populaarsuse, aga sai kahjuks juba üsna pea üheks mõistatuste kopeerimise allikaks ja repertuaari kujundajaks ning lähetati arvukate kogujate ümberkirjutustes taas käsikirjadena Matthias Johann Eiseni või Jakob Hurda postkasti.

\section{“Devinettes Estiniennes" (1894)}

Mulle oli suureks üllatuseks avastus, et Matthias Johann Eiseni Eesti rahva mõistatusi tutvustati ka rahvusvahelisele publikule. 1890. aastast tegutses Pariisis literaat, ajakirjanik ja õpetaja Andres Dido (1855-1921), poliitilistel põhjustel Baltimaadelt väljasaadetu. Ajakirjas Revue des traditions populaires avaldas ta eesti folkloori tutvustavaid materjale, muu hulgas 1894. aastal kirjutise 


\section{Rein Saukas}

M. J. Eiseni mõistatusteraamatu kohta. Neljal leheküljel on pealkirja "Devinettes Estiniennes" all A. Dido koostatud, M. J. Eiseni raamatu eessõnale toetuv lühitutvustus ja 50 mõistatuse tõlge prantsuse keelde.

A. Dido kirjutab, et Matthias Johann Eiseni kogumikus on kümme pikka mõistatuslaulu ja 1770 proosamõistatust. Nendest osa olevat M. J. Eisen ise kogunud, osa aga laenanud teistest kogumikest, ilmselt siis trükistest. 1882. aastast kuni augustini 1893 olevat M. J. Eisen üksi kogunud üle 9000 mõistatuse. (Kas A. Dido vahendab siin M. J. Eisenilt otse või kaudseid allikaid pidi saadud informatsiooni, pole selge. Täiesti vale on aga tema väide, nagu kogunuks M. J. Eisen mõistatused üksi.) Mõistatused moodustavat eesti rahvaluulest olulise osa: Kalevipoja kangelased peavad hiiglase käest pääsemiseks lahendama mõistatusi; mõnikord peab peigmees lahendama mõistatusi, et saavutada neiu juures edu; samuti on surmamõistetud mõistatusi ära arvates oma elu päästnud. M. J. Eiseni kogumiku mõistatused rääkivat loomadest, taimedest, tööriistadest, ehitustest, kehaosadest, loodusnähtustest jne. Viimaseid olevat teiste kategooriatega võrreldes vähem ja need ei näitavat nii palju tarkust ja ilu, aga pakkuvat seevastu uurijatele suuremat huvi.

Järgnevad näited kahest rubriigist:

"I. Loodusnähtused", kus on esitatud 40 mõistatust jõe, mere, maa, lume, külma, rahe, vihma, pilve, tuule, välgu, müristamise, taeva, vikerkaare, päikese, kuu, udu, varju, pimeduse kohta;

"II. Varia" pakub 10 erinevat mõistatust, sealhulgas viis keerdküsimust.

Olgu siin esitatud mõned näited A. Dido valikust, mille kaudu prantsuse keelt valdavad lugejad eesti mõistatustega tutvust said teha:

Harjumaale ahatakse, Virumaale visatakse? Välk;

Must ema, valge kuub? Lumi maas;

Kena viibuline, lindi triibuline, käib lookas üle maa, keegi kätte ei saa? Vikerkaar;

Kas lähed hagadest aeda mööda või laudsilda mööda? Taeva ja põrgu tee;

Kõik maailm verd täis, tapetud pole kedagi? Koit (Dido 1894: 33-35). 


\section{Kokkuvõtteks}

Matthias Johann Eiseni 1887.-1888. aastate tööl on meie rahvaluulekogumise ajaloos kindlasti kaalukas osa. Ta alustas seda aktsiooni, kui rahvaluulekorjamine oli madalseisus, ja lõpetas, kui Jakob Hurda algatatud rahvuslik suurüritus oli laineharjal.

M. J. Eiseni vabatahtlikud kaastöölised olid haritud inimesed, kes tegid mõistatuste kirjapanekud valdavalt hindele väga hea (trükistest mahakirjutajaid ja omaloomingu harrastajaid on olnud alati). Nende saadetised kogus SKS, Eisen annavad üsna hea läbilõikelise pildi rahva seas käibinud mõistatustest nendel paaril aastal. Kahjuks ei ole esindatud omanäolise repertuaariga Setumaa, vähe on saarte mõistatusi. Kogujad tunnetasid oma töö tähtsust ja ilmselt ootasid M. J. Eisenilt tõhusamat juhendamist ja suunamist, nad tegid õieti rohkem kui M. J. Eisen neilt nõudis või nõuda oskas mõtlen siin kaaskirjades leiduvat huvitavat ja materjali täiendavat informatsiooni. Nende pilk mõistatuste maailmale ja mõistatuste talletamisele tundub olevat avaram ja rohkem tulevikku suunatud kui M. J. Eiseni enda oma.

Matthias Johann Eiseni töö hindamisel tuleks eelkõige arvestada asjaolu, et rahvaluulekogumine oli talle nendel aastatel kõrvalharrastus igapäevase ametitöö ja keerulise isikliku elu kõrval. Endale seatud eesmärgi - avaldada vähemalt E. Lönnroti raamatu mahuga võrdne kogumik eesti mõistatusi - ta täitis. Eesti rahva mõistatustega sai M. J. Eiseni arvates see rahvaluuleliik tulevastele põlvedele talletatud, jäi veel korraldada seni kirja panemata mõistatuste kogumine, mida ta 1890. aasta maikuust alates ka tegema asus.

Kõnesolnud mõistatuste kogumise aktsioonist sai alguse kogu M. J. Eiseni hilisem rahvaluule kogumistöö, eelnenu oli juhuslik ja marginaalne. Selles mõttes oli Matthias Johann Eisen algaja ja õppija. Tegelikult oli tal kogemustega vanem kolleeg Jakob Hurda kujul olemas, iseasi kui palju ta viimaselt eelnevalt nõu küsis. (M. J. Eisen ja J. Hurt puutusid kokku nii Eesti Kirjameeste Seltsis kui ka Eesti Üliõpilaste Seltsis, samuti ametivendadena. ${ }^{15}$ ) Ometi mõjutas Jakob Hurda 1888. aasta veebruaris-märtsis alanud kogumistöö M. J. Eiseni arusaamu selle töö korraldamisest ja suhtlemisest kaastöölistega.

Kogu Matthias Johann Eiseni tegevust mõistatuste kogumise lühikese aktsiooni vältel iseloomustab aga siiski kärsitus ja kiirus- 


\section{Rein Saukas}

tamine, pealiskaudsus, süsteemipuudus ja kohati isegi asjatundmatus. Praegusaja arusaamade kohaselt tundub lausa kuritegelik tema viis eesti mõistatuste repertuaari soome mõistatuste tõlgetega rikastada. Kui võrrelda või kõrvutavalt lugeda SKS, Eisen mõistatuste korjandusi ja nende põhjal koostatud Eesti rahva mõistatu$s i$, kaldub vaekauss kindlalt esimese kasuks.

Eesti rahva mõistatused koos selle 1913. aastal ilmunud täiendatud trükiga Eesti mõistatused jäid aga kuni akadeemilise publikatsiooni koostamiseni mahukaimateks eesti mõistatusi sisaldanud trükisteks. Nüüd, kui on ilmunud tänapäeva folkloristika taset arvestavad mõistatuste publikatsioonid, on M. J. Eiseni raamat vajunud unustusse, tema lühikese kogumisaktsiooni heatasemelised kirjapanekud jäävad aga rikastama Eesti Rahvaluule Arhiivi kogusid.

\section{Kommentaarid}

${ }^{1}$ C. E. Mötleja. Mõistatuste raamat. Esimene korjandus (Tallinn 1878); Matthias Johann Eisen. Eesti rahva mõistatused (Tartu 1889 [1890]); Matthias Johann Eisen. Mõista, mis see on? (Tallinn [1904]); Matthias Johann Eisen. Eesti mõistatused. 2., täiend tr (Tartu 1913); Matthias Johann Eisen. Mõista, mõista, mis see on. Mõistatused, keerulised küsimised ja mõistatuse-jutud (Tartu [1914]); Matthias Johann Eisen. Mõista, mõista, mis see on. Mõistatused, keerulised küsimised ja mõistatuse-jutud. 2., täiend tr (Tartu 1920); Vilma Metstak (koost). Mõista, mõista... Eesti rahva mõistatusi (Tallinn 1979); Vilma Metstak (koost). Mõista, mõista... Eesti rahva mõistatusi (Tallinn 1992); Aive Asperg (koost). Mõistatused ([Rapla 1993]); Matthias Johann Eisen. Mõista, mõista, mis see on. Mõistatused, keerulised küsimised ja mõistatuse-jutud ([Tallinn] 1994); Piret Voolaid (koost). Elevant külmkapis. Kimbuke keerdküsimusi eesti koolilaste suust (Tallinn 1998); Arvo Krikmann (koost). Tere teele, tere meele, tere egalõ talolõ. Valik lõunaeesti mõistatusi (Tartu 2000).

${ }^{2}$ Niisama pole ma peale näiteeksemplari veel väikest "Kasulist Talurahva Kalendrit" saanud, mis see aasta enamiste kõik ka minu kirjutatud (Matthias Johann Eisen Kaarle Krohnile 8. detsembril 1886.

3 Jaan Lievoh (1862-1935) oli kooliõpetaja ja koolijuhataja Noarootsis, hiljem Hiiumaal, tõlkinud ja avaldanud vaimuliku sisuga raamatuid ja artikleid ajakirjanduses (Laulu ja Mängu Leht, Postimees, Uus Aeg, Perekonna Leht) - vt EKLA, f 116, m 8: 4.

${ }^{4}$ M. J. Eisen näib siin välistavat mõistatuste hilisema laenamise, mis naaberrahvaste vahel on üsna tavaline. 


\section{Rein Saukas}

5 1) Eesti mõistatuste asjus. Postimees 27, 3. märts 1888, lk 1; Eesti vanade mõistatuste asjus. Olevik 12, 21. märts 1888, lk 1; Eesti rahva mõistatused. Valgus 16, 14. aprill 1888, lk 2; Eesti rahva mõistatused. Sakala 15, 16. aprill 1888, lk 2; 2) Veel Eesti rahva mõistatustest. Postimees 43, 9. aprill 1888, lk 2; 3) 1200 vana Eesti mõistatust. Olevik 17, 23. aprill 1888, lk 1; Eesti rahva mõistatused. Virulane 18, 2 . mai 1888, lk 1; 4) Eesti vanade mõistatuste korjamise aruanne. Postimees 50, 3. mai 1888, lk 1; 5) Eesti mõistatused. Olevik 23, 6. juuni 1888, lk 1; 6) Eesti mõistatuste korjamise aruanne. Postimees 74, 5. juuli 1888, lk 1; Eesti mõistatuste korjamisest. Olevik 28, 11. juuli 1888, lk 1; Korjamiste aruanne. Virulane 29,18. juuli 1888, lk 2; 7) Eesti rahvamõistatused. Postimees 106, 17. september 1888, lk 1; Eesti mõistatusi on mulle viimasel ajal jälle saatnud... Virulane 35, 29. august 1888 , lk $1 ; 8$ ) Eesti rahva mõistatustest. Olevik 44, 31. oktoober 1888, lk 2; 9) Eesti rahva mõistatused. Postimees nr 144, 15. detsember 1888, lk 2; Eesti rahva mõistatused. Olevik 51, 19. detsember 1888, lk 2.

${ }^{6}$ M. J. Eisen peab siin silmas E. Lönnroti kogumiku teist trükki, kus on enam kui 2200 alfabeetiliselt järjestatud mõistatust, mille hulgas on nii mõnigi kord ühest ja samast tüübist mitu varianti, seega on E. Lönnroti kogumiku mõistatustüüpide arv hoopis väiksem, kui M. J. Eisen arvab.

7 Siin M. J. Eisen eksib - Järvamaa materjali hulka tuleks arvata eespool nimetatud P. A. Pitka üleskirjutused 13. aprillist.

8 Jüri Tilgal ja teistel Tori ärksamatel meestel kujunesid M. J. Eiseniga tihedad koostöösidemed. M. J. Eiseni karskusteemalised kirjutised 1887. aasta Isamaa Kalendris ja Kasulises Talurahva Kalendris ärgitasid Jüri Tilka organiseerima Toris Eesti esimest karskusseltsi Täht (Looring 1938: 187). Tori meeste ühine seltsitegevus võis anda innustust ka rahvaluule kogumiseks.

${ }^{9}$ M. J. Eiseni ja J. Hurda paralleelsest tegevusest rahvaluulekogumisel on põhjalikult kirjutanud Ülo Tedre (Tedre 1994b), seepärast on käesolevas kirjutises üksnes teemakohaseid notiitse.

${ }^{10}$ Mägi varasemad rahvaluulesaadetised sisaldavadki kõik Karksi materjali, alles hiljem hakkab ta kirja panema kohalikku ainest.

11 Vt näiteks Gustav Kolgi Mõistatuse raamat 1885. aastast (RKM, AK 881) või Gerda Lipu miniklade 1903. aastast (RKM II 345, 145-180).

12 Vähesed kättepuutunud andmed ei luba väga kindlalt väita, et siin on tegemist Tõnis Tilgaga (2.03.1866-29.05.1958), kelle kohta on 1963. aasta Tori ekspeditsioonil suulisest traditsioonist üksikuid fakte üles tähendanud Erna Tampere. Vt RKM II 157, 389. Nimetatud Tõnist ei ole ka Tilkade sugupuu andmebaasis (www.aai.ee/ urmas/gen/t2599.html - 8.06.2003).

${ }^{13}$ Mõni aasta hiljem on M. J. Eisen tunduvalt ausam ja avameelsem. Nii kirjutab ta aprillis 1891 Kaarle Krohnile: Praegu on mul trükis "Kodune lauluraamat”, mis nädali pärast vist ilmub. Ses raamatus on 64 minu oma 


\section{Rein Saukas}

tehtud vaimulikku laulu, neist mitmed Soome lauluraamatust võetud. Ka sinu isa laulusid olen 2-3 seal ümber pannud. Laulikus on M. J. Eisen üheksale laulule lisanud märkuse: Soome lauluraamatust või Soome keelest või Runebergi järele või Krohni järele (Eisen 1891).

${ }^{14}$ Viimased viis laulu sai M. J. Eisen tõenäoliselt Oskar Kallaselt. Nende laulude arhiiviüleskirjutused asuvad praegu: H II 18, 622-623 (85) < Kaarma - J. Kappel (1889) ning Oskar Kallase ja Mihkel Ostrovi 1889. aasta Läänemaa kogumismatka materjalide hulgas (H II 2, 38-39 (62), 307-308 (436), 354 (479), 355 (480)).

${ }^{15}$ Lempaalast sõitsin Peterburisse tagasi, kus Dr Hurti juures korteris olin, kirjutab Matthias Johann Eisen Kaarle Krohnile 1. septembril 1887. Samas kirjas teatab ta ka mõistatuste kogumise alustamisest.

\section{Kirjandus}

\section{Käsikirjad}

EFAM [Eesti folkloristika ajaloo materjalid] ERA, M.1A.

EKLA [Eesti Kultuurilooline Arhiiv], f 116, m 8: 4 - Jaan Lievoh (18621935) matarjalid.

H II 2, 38-39 (62), 307-308 (436), 354 (479), 355 (480)) - Oskar Kallase ja Mihkel Ostrovi Läänemaa kogumismatka materjalid (1889).

H II 18, 622-623 (85) < Kaarma - J. Kappel (1889).

Matthias Johann Eiseni kirjad Kaarle Krohnile 8. detsembrist 1886, 1. septembrist ja 16 . novembrist 1887,20 . aprillist ja 29 . novembrist 1888 , 17. septembrist 1889,21 . veebruarist ja 28 . aprillist 1890 , aprillist 1891 , 20. aprillist ja 7. detsembrist 1892 ning 3. jaanuarist 1893. Kirjavahetuse masinakirjakoopiad asuvad Eesti Kirjandusmuuseumi Eesti Rahvaluule Arhiivis.

RKM II 345, 145-180 - Gerda Lipp. [Miniklade ] (1903).

RKM, AK 881 - Gustav Kolk. Mõistatuse raamat (1885).

SKS, Eisen 1-495 - Matthias Johann Eiseni mõistatuste kogumise aktsiooni materjalid 1887-1888.

SKS, Eisen 2 - Carl Martin Redlich. Kiri Matthias Johann Eisenile 12. novembrist 1887.

SKS, Eisen 6 - Carl Martin Redlich. Kiri Matthias Johann Eisenile 19. veebruarist 1888 . 


\section{Rein Saukas}

SKS, Eisen 26 - Juhan Aab. Kiri Matthias Johann Eisenile 18. septembrist 1888 .

SKS, Eisen 30, 34 - Mart Tamm. Kiri Matthias Johann Eisenile 6. augustist 1888 .

SKS, Eisen 58 - Villem Kullerkupp. Dateerimata kiri Matthias Johann Eisenile.

SKS, Eisen 63-64 - Peäro August Pitka (Ansomardi). Kiri Matthias Johann Eisenile 13. aprillist 1888.

SKS, Eisen 87 - Heinrich Tiidermann. Kiri Matthias Johann Eisenile 29. juulist 1888 .

SKS, Eisen 97 - J. Pikkel. Kiri Matthias Johann Eisenile 8. maist 1888.

SKS, Eisen 151 - Jaan Lievoh. Kiri Matthias Johann Eisenile 27. septembrist 1887.

SKS, Eisen 204 - Karl Kirschbaum. Kiri Matthias Johann Eisenile 7. juulist 1888 .

SKS, Eisen 205-206 - Jüri Tilk. Kiri Matthias Johann Eisenile 8. novembrist 1887.

SKS, Eisen 213-214 - Jüri Tilk. Kiri Matthias Joahnn Eisenile 18. juunist 1888.

SKS, Eisen 121-136 - Matthias Johann Eiseni 12-aastase Oese koolipoisina koostatud vihikuke Mõistatusse ramat 1869. aastast.

SKS, Eisen 222 - Jüri Tilk. Kiri Matthias Johann Eisenile 23. novembrist 1887.

SKS, Eisen 230, 235 - Mihkel Tilk. Kiri Matthias Johann Eisenile 10. aprillist 1888 .

SKS, Eisen 259 - Jaan Mieländer. Kiri Matthias Johann Eisenile 17. juunist 1888 .

SKS, Eisen 276 - Johann Mägi. Kiri Matthias Johann Eisenile 16. oktoobrist 1888 .

SKS, Eisen 325-326 - Jaan Jaakson. Kiri ja mõistatused Matthias Johann Eisenile 2.-24. maist 1888.

SKS, Eisen 304 - Hans Utso. Dateerimata kiri Matthias Johann Eisenile.

SKS, Eisen 334 - Jaan Leppik. Dateerimata kiri Matthias Johann Eisenile.

SKS, Eisen 353 - Jakub Reial. Kiri Matthias Johann Eisenile 1888.

SKS, Eisen 385, 386 - Helene Maasen. Kiri Matthias Johann Eisenile 21. septembrist 1888 . 


\section{Rein Saukas}

SKS, Eisen 404. Jaan Kripson. Kiri Matthias Johann Eisenile 7. juulist 1888.

SKS, Eisen 405 - Joh. Voites. Kiri Matthias Johann Eisenile 25. märtsist 1888.

SKS, Eisen 412 - Voldemar Grünstamm. Kiri Matthias Johann Eisenile maist 1888.

SKS, Eisen 426 - J. Paap. Kiri Matthias Johann Eisenile 1887. aastast.

SKS, Eisen 437, 440 - Jakob Puksov. Kiri Matthias Johann Eisenile 5. oktoobrist 1888 .

\section{Trükised}

Ahlqvisti, August (toim) 1869. Suomalainen murteiskirja tahi lukemisia viron, karjalan, vatjan, vepsän ja liivin kielillä: Suomalaisten sanastojen kanssa. Helsingi: Simeliuksen kirjapainos.

Asperg, Aive (koost) [1993]. Mõistatused. [Rapla]: Kallike.

C. E. Mötleja [= Malm, Carl Eduard] 1878. Mõistatuste raamat: Esimene korjandus. Tallinn: K. E. Malm.

Dido, Andres 1894. Devinettes Estiniennes. Revue des traditions populaires IX, lk 32-35.

Eisen, Matthias Johann 1867 [1876]. Nalja Sõber: Noore rahvale armsaks ajaviiteks. Tartu: Schnackenburg.

Eisen, Matthias Johann 1882. Esivanemate varandus: Kohalised Eesti muinasjutud. Tartu: Schnakenburg.

Eisen, Matthias Johann 1883a. Soov ja palve. Eesti Postimees 7, 16. veebruar 1883 , lk 3 .

Eisen, Matthias Johann 1883b. Endise põlve pärandus I. Tartu: Schnakenburg.

Eisen, Matthias Johann 1887a. Tänini on ju mitmesugu.... Postimees 37, 5. september, lk 3 .

Eisen, Mathhias Johann 1887b. Tänini on ju mitmet sugu... Virulane 37, 7. september, lk 2.

Eisen, Matthias Johann 1887c. Tänini on ju mitmesugu... Meelejahutaja 37, 8. september, lk 295.

Eisen, Matthias Johann 1887d. Tänini on ju mitmesugust... Olevik 39, 21. september, lk 2 .

Eisen, Matthias Johann 1887e. Meid palutakse... Sakala 40, 3 oktoober, lk 3. 


\section{Rein Saukas}

Eisen, Matthias Johann 1887f. Eesti mõistatused. Olevik 44, 26. oktoober 1887, lk 1 .

Eisen, Matthias Johann 1888a. Eesti mõistatuste asjus. Postimees 27, 3. märts, lk 1 .

Eisen, Matthias Johann 1888b. Eesti vanade mõistatuste asjus. Olevik 12, 21. märts, lk 1.

Eisen, Matthias Johann 1888c. Veel Eesti rahva mõistatustest. Postimees 43, 9. aprill, lk 2 .

Eisen, Matthias Johann 1888d. Eesti rahva mõistatused. Valgus 16, 14. aprill, lk 2.

Eisen, Matthias Johann 1888e. Eesti rahva mõistatused. Sakala 15, 16. aprill, lk 2.

Eisen, Matthias Johann 1888f. 1200 vana Eesti mõistatust. Olevik 17, 23. aprill, lk 1.

Eisen, Matthias Johann 1888g. Eesti rahva mõistatused. Virulane 18, 2. mai, lk 1 .

Eisen, Matthias Johann 1888 h. Eesti vanade mõistatuste korjamise aruanne. Postimees 50, 3. mai, lk 1 .

Eisen, Matthias Johann 1888i. Eesti mõistatused. Olevik 23, 6. juuni, lk 1.

Eisen, Matthias Johann 1888j. Eesti mõistatuste korjamise aruanne. Postimees 74, 5. juuli, lk 1.

Eisen, Matthias Johann 1888k. Eesti mõistatuste korjamisest. Olevik 28,11 . juuli, lk 1 .

Eisen, Matthias Johann 18881. Korjamiste aruanne. Virulane 29, 18. juuli, lk 2 .

Eisen, Matthias Johann 1888m. Eesti mõistatusi on mulle viimasel ajal jälle saatnud... Virulane 35,29 . august, lk 1 .

Eisen, Matthias Johann 1888n. Eesti rahvamõistatused. Postimees 106, 17. september, lk 1 .

Eisen, Matthias Johann 18880. Eesti rahva mõistatustest. Olevik 44, 31. oktoober, lk 2.

Eisen, Matthias Johann 1888p. Eesti rahva mõistatused. Postimees 144, 15. detsember, lk 2.

Eisen, Matthias Johann 1888r. Eesti rahva mõistatused. Olevik 51, 19. detsember, lk 2.

Eisen, Matthias Johann 1889 [1890]. Eesti rahva mõistatused. Tartu: K. A. Hermann. 


\section{Rein Saukas}

Eisen, Matthias Johann 1891. Kodune lauluraamat I. Tallinn: K. Busch. Eisen, Matthias Johann [1904]. Mõista, mis see on? Tallinn: K. Busch.

Eisen, Matthias Johann 1913. Eesti mõistatused. 2., täiend tr. Tartu: Postimees.

Eisen, Matthias Johann [1914]. Mõista, mõista, mis see on: Mõistatused, keerulised küsimised ja mõistatuse-jutud. Tartu: Postimees.

Eisen, Matthias Johann 1920. Mõista, mõista, mis see on: Mõistatused, keerulised küsimised ja mõistatuse-jutud. 2., täiend tr. Tartu: G. Roht.

Eisen, Matthias Johann 1921. Miten minusta tuli kansanrunouden kerääjä ja Kalevalan harrastaja. Kalevalaseuran vuosikirja 1. Helsinki 1921, lk 194-202.

Eisen, Matthias Johann 1925. Kuidas ma kirjameheks sain. Eesti Kirjandus 9 , lk 343-350.

Eisen, Matthias Johann 1932. Pro domo. Eesti Kirjandus 10, lk 528.

Eisen, Matthias Johann 1994. Mõista, mõista, mis see on: Mõistatused, keerulised küsimised ja mõistatuse-jutud. [Tallinn]: Perioodika.

Hermann, Karl August 1890. Tähtjas raamat. Postimees 47, 28. aprill, lk 1.

Hurt, Jakob 1887. Lühikene teadus ja tähtis palumine. Virulane 23, 1. juuni 1887, lk 2 .

Hurt, Jakob 1888a. Paar palvid Eesti ärksamaile poegadele ja tütardele. Olevik 8, 22. veebruar, lk 1; 9, 29. veebruar, lk 1, 10, 7. märts, lk 1.

Hurt, Jakob 1888b. Esimene aruanne Eesti vana vara korjamisest ja keelemurrete uurimisest. Olevik 13, 28. märts, lk 1.

Hussar, Anne \& Krikmann, Arvo \& Normann, Erna \& Pino, Veera \& Sarv, Ingrid \& Saukas, Rein 1980-1988. Eesti vanasõnad (= Proverbia Estonica) I-V. Tallinn: Eesti Raamat.

Hussar, Anne \& Krikmann, Arvo \& Saukas, Rein \& Voolaid, Piret 2001-2002. Eesti mõistatused (= Aenigmata Estonica) I-II. Tartu: Eesti Keele Sihtasutus.

Isamaa Kalender 1879. aasta peale. 1878. Tartu: Schnackenburg.

Jannsen, Johann Voldemar 1857. Kues Sannumetoja aastal 1857, Ehk Uut ja wanna Ma-rahwa römuks ja öppetusseks. Tartu: H. Laakmann.

Krikmann, Arvo (koost) 2000. Tere teele, tere meele, tere egalõ talolõ: Valik lõunaeesti mõistatusi. Tartu: [Eesti Kirjandusmuuseum].

Krohn, Kaarle 1902. Die Märchen- und Sagenpublikationen von M. J. Eisen. Anzeiger der Finnisch-Ugrischen Forschungen II: 2. Helsingfors \& Leipzig, lk 71-77. 


\section{Rein Saukas}

Liiv, Jaan 1879. Laste Mängu-tuba: Mitmesugused ilusad tua-ja õue mängud, kui ka mitmesugused naljatused ja vanad-sõnad. Tartu: Schnakenburg,

Looring, Aleksander 1938. Matthias Johann Eisen karsklasena. Friedrich Ederberg \& Elmar Päss (toim). M. J. Eiseni elu ja töö. Tartu: NoorEesti, lk 185-190.

Lönnrot, Elias (koost) 1844. Suomen Kansan Arvoituksia ynnä 135 Viron Arvoituksen kanssa. Helsinki: Suomalainene Kirjallisuuden Seura.

Lönnrot, Elias (koost) 1851. Suomen kansan Arvoituksia ynnä 189 Viron Arvoituksen kanssa. Toinen lisännetty painos. Helsinki: Suomalainene Kirjallisuuden Seura.

Marahwa Näddala-Leht 1821-1822. Toim Otto Wilhelm Masing.

Metstak, Vilma (koost) 1979. Mõista, mõista...: Eesti rahva mõistatusi. Tallinn: Eesti Raamat.

Metstak, Vilma (koost) 1992. Mõista, mõista...: Eesti rahva mõistatusi. Tallinn: Tiritamm.

Normann, Erna 1961. Matthias Johann Eiseni mõistatuste ja vanasõnade trükiväljaanded. Paar sammukest eesti kirjanduse ja rahvaluule uurimise teed: Uurimusi ja materjale 2. Tartu: Eesti NSV Teaduste Akadeemia, lk 422-434.

Postimees 42, 22. veebruar 1893; 82, 26. juuli 1890.

Päss, Elmar 1938a. Lisandeid M. J. Eiseni bibliograafiale. Friedrich Ederberg \& Elmar Päss (toim). M. J. Eiseni elu ja töö. Tartu: Noor-Eesti, lk 191-213.

Päss, Elmar 1938b. Eiseni rahvaluulekogudest. Friedrich Ederberg \& Elmar Päss (toim). M. J. Eiseni elu ja töö. Tartu: Noor-Eesti, lk 133-139.

Sakala 15, 16. aprill 1888, lk 2.

Suomalaisen Kirjallisuuden Seuran keskustelemukset v 1892-1893. Suomi III: 7. Helsinki 1893, lk 1-122.

Tedre, Ülo 1994a. M. J. Eiseni tee folkloristikasse (I): "Esivanemate varandusest" "Eesti rahva mõistatusteni". Keele ja Kirjandus 6, lk 335-345.

Tedre, Ülo 1994b. M. J. Eiseni tee folkloristikasse (II): Eisen Hurda võistlejana. Keel ja Kirjandus 8, lk 487-497.

Thompson, Stith 1964. The Types of the Folktale: A Classification and Bibliography: Antti Aarne's Verzeichnis der Märchentypen. Helsinki: Suomalainen Tiedeakatemia.

Wiedemann, Ferdinand Johann 1876. Aus dem inneren und äusseren Leben der Ehsten. St. Petersburg: Keiserliche Akademie der Wissenschaften. 


\section{Rein Saukas}

Viidebaum (= Viidalepp), Richard \& Loorits, Oskar 1932. Eesti rahvaluulekogude statistiline ülevaade. Vanavara vallast: Oppetatud Eesti Seltsi Kirjad 1. Tartu: Õpetatud Eesti Selts, lk 195-219.

Willmann, Friedrich Wilhelm 1782. Juttud ja teggud, kui ka Monningad Öppetused mis majapiddamisse pärrast tarvis lähtvad. Tallinn: Lindforss. Voolaid, Piret (koost) 1998. Elevant külmkapis: Kimbuke keerdküsimusi eesti koolilaste suust. Tallinn: Koolibri. 